This item was submitted to Loughborough's Research Repository by the author.

Items in Figshare are protected by copyright, with all rights reserved, unless otherwise indicated.

\title{
Sediments and landforms in an upland glaciated-valley landsystem: upper Ennerdale, English Lake District
}

PLEASE CITE THE PUBLISHED VERSION

\section{PUBLISHER}

Blackwell Publishing / @ International Association of Sedimentologists

VERSION

AM (Accepted Manuscript)

\section{LICENCE}

CC BY-NC-ND 4.0

\section{REPOSITORY RECORD}

Graham, David J., and Michael J. Hambrey. 2019. "Sediments and Landforms in an Upland Glaciated-valley Landsystem: Upper Ennerdale, English Lake District”. figshare. https://hdl.handle.net/2134/5893. 
This item was submitted to Loughborough's Institutional Repository (https://dspace.lboro.ac.uk/) by the author and is made available under the following Creative Commons Licence conditions.

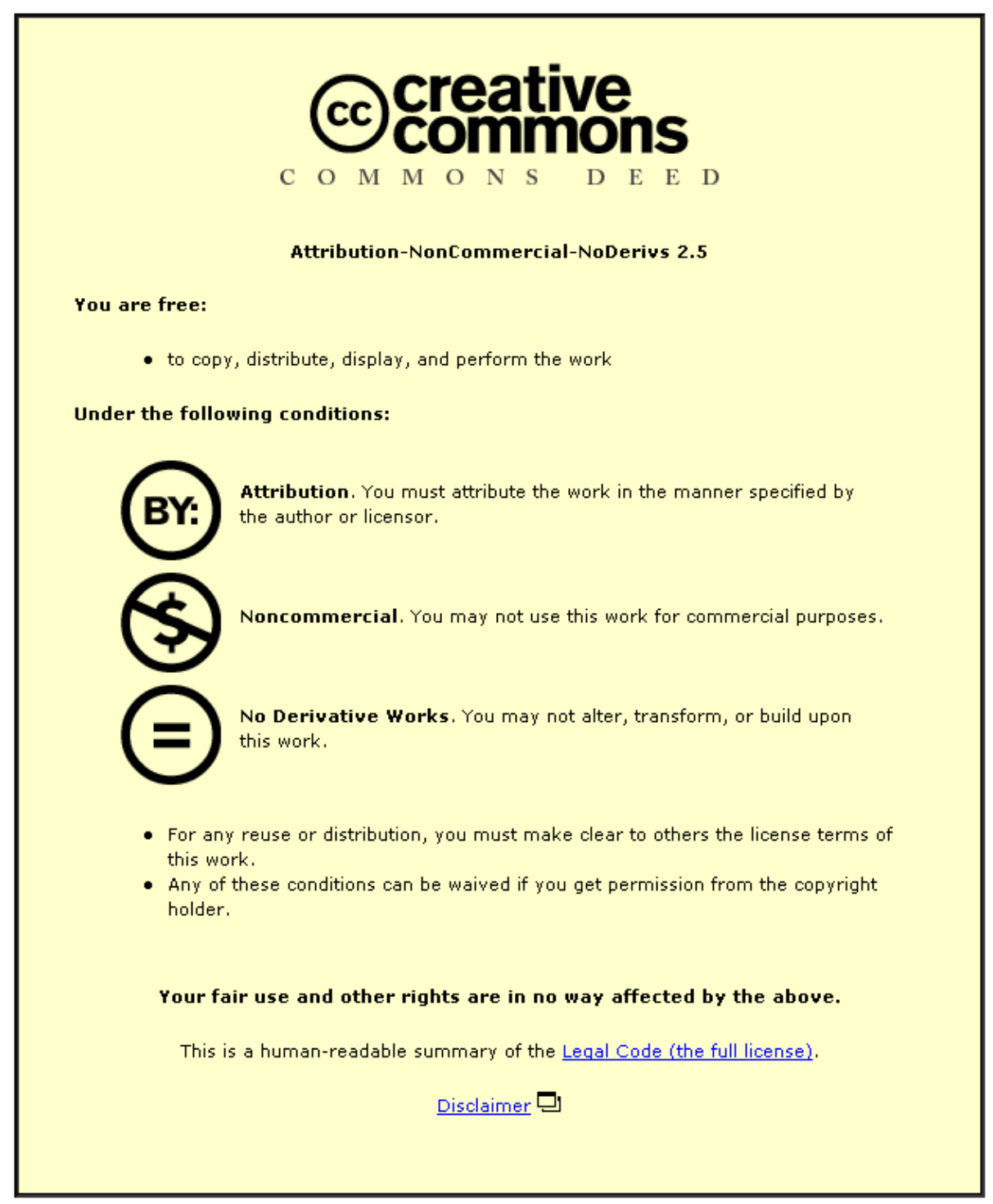

For the full text of this licence, please go to: http://creativecommons.org/licenses/by-nc-nd/2.5/ 


\section{Sediments and landforms in an upland glaciated-valley}

\section{landsystem: upper Ennerdale, English Lake District}

DAVID J. GRAHAM ${ }^{1}$ and MICHAEL J. HAMBREY

Centre for Glaciology, Institute of Geography and Earth Sciences, University of

Wales, Aberystwyth, SY23 3DB, UK (E-mail: D.J.Graham@lboro.ac.uk)

${ }^{1}$ Present address: Department of Geography, Loughborough University,

Loughborough, Leicestershire, LE11 3TU, UK.

Running title: Sediments and landforms in an upland glaciated-valley

Note to editor

Corresponding author: David J. Graham, Department of Geography, Loughborough University, Loughborough, Leicestershire, LE11 3TU, UK

(D.J.Graham@lboro.ac.uk) 


\section{ABSTRACT}

The genesis of moraines associated with British glaciers of Younger Dryas age has proved controversial in recent years. A number of alternative hypotheses exist and, whilst it is generally accepted that such features are polygenetic in origin, some workers have argued that not all of the proposed mechanisms are valid. This paper seeks to explore these issues, using a case study from the English Lake District. A landsystems approach is adopted, integrating information at a variety of spatial scales to explain the development of the sediment-landform associations in upper Ennerdale. The evidence suggests that landform development resulted from a combination of icemarginal deposition and englacial thrusting. It is probable that thrusting resulted from flow compression against a reverse bedrock slope, combined with the confluence of ice from two separate source areas. It is argued that, whilst englacial thrust moraines may not be commonly associated with British Younger Dryas glaciers, under certain conditions englacial thrusting is an important process in landform development.

Keywords Glacial geomorphology, glacial landsystems, moraine, Younger Dryas, Loch Lomond Stadial, English Lake District, glacial processes. 


\section{INTRODUCTION}

The suite of landforms and sediments found at glacier margins varies according to thermal regime, relief and tectonic setting. Comparison between modern environments and palaeoenvironments is essential if reliable reconstructions of past glacier extent and conditions are to be derived. By comparing the sediments and landform morphology with modern glaciers, this paper aims to reconstruct the Younger Dryas (Loch Lomond stade) glacial conditions in part of the Lake District, a classic area for the study of upland glaciation in the UK. This area, which is of moderate relief $(700-900 \mathrm{~m})$, is typical of many tectonically stable mountain belts, and lacks the precipitous slopes that are common in tectonically active regions.

Apparently chaotic associations of moraine mounds and ridges are characteristic of many former Younger Dryas glaciers in the UK. They are commonly known as 'hummocky moraine' (Sissons, 1979), but the term 'moraine-mound complex' is preferred because of the genetic connotations associated with the former (following Bennett et al., 1996b). The significance of such moraine-mound complexes has been controversial (Bennett, 1994). Early workers applied Alpine analogues and interpreted all moraines as indicative of ice-marginal positions (e.g. Charlesworth, 1956). In the 1960s and 1970s, the Sissons school interpreted moraine-mound complexes as products of large-scale areal stagnation, similar to that described from Scandinavia and North America (Sissons, 1980; Gray, 1982). Later, Eyles (1983) applied an Icelandic analogue and proposed that the features result from incremental stagnation of a glacier margin undergoing active recession. In the 1990s, work by Benn (1990; 1992) and Bennett (1991; Bennett and Boulton, 1993a) led to the 
conclusion that moraine-mound complexes are polygenetic in origin, representing icemarginal landforms associated with active glacier recession and oriented perpendicular to ice flow, subglacial bedforms oriented parallel to ice flow, and small areas of stagnation topography with no discernable organisation. The ice-marginal landforms were used by Bennett (1991) to reconstruct the pattern of deglaciation in the northwest Highlands of Scotland. Subsequently, by analogy with landforms developed at polythermal glaciers in Svalbard, it has been proposed that some moraine-mound complexes in Britain may be englacial thrust moraines (Hambrey et al., 1997). Such features are oriented approximately perpendicular to glacier flow, but are associated with the internal structure of the glacier and do not represent icemarginal positions. However, the inference of thrusting has proved controversial. Firstly, the interpretation by Bennett et al. (1998) of a classic moraine-mound complex in Glen Torridon, NW Scotland as a thrust-moraine complex, was refuted by Wilson \& Evans (2000). Then, Lukas (2005) stated that the thrust hypothesis for British Younger Dryas moraines was universally incorrect, although his study was based on a quite different set or morainic landforms in Sutherland, NW Scotland (Graham et al., submitted). These differences of opinion highlight the need to investigate Younger Dryas moraines on a case-by-case basis, combining detailed analysis of sedimentary facies and landform morphology.

The changing interpretations of British moraine-mound complexes illustrate how the sediment-landform associations that record the presence and nature of glaciers in the past can be interpreted in different ways. Even at contemporary glaciers, where landform-generating processes may be observed and the sedimentological and morphological products of these processes are well preserved 
and exposed, different researchers often cannot agree. This is to be expected, given the extremely complex interaction of glacial, fluvial, gravity-driven and, commonly, aeolian and lacustrine or marine processes operating. In the palaeolandform record, where the morphology may have been subject to thousands of years of postglacial modification and the sedimentary exposure is commonly poor, the challenges are even greater.

Partially as a response to this complexity, much recent glacial sedimentological and geomorphological work has adopted a landsystems approach (Evans, 2003a). This approach recognises that the landscape is composed of a range of related elements at a variety of spatial scales, and that understanding the significance of individual elements requires an appreciation of their environmental context. This framework enables the significance of individual landscape elements to be understood in the context of the wider landscape associated with a particular glacier system. Further, the approach facilitates the creation of a range of processform models relating particular styles of glaciation and their characteristic products at a range of spatial scales (Benn and Evans, 1998). Such models may be applied to assist researchers in interpreting landforms of uncertain origin in both the contemporary and ancient landform record.

A particular benefit of the landsystems approach is that the application of a particular model at a field site does not require full information about the nature of the sediments and landforms present. Provided that the information available is sufficient to allow confident application of an existing landsystem model, inferences may be made about the nature of any missing information. So for example, in the absence of 
extensive sedimentary exposure within a landform, inferences may be made about the likely nature of the constituent facies and their architecture based on the application of a model that fits the available evidence. Conversely, a danger of the landsystems approach is that it is possible to over interpret a landscape, applying a particular model where the evidence is insufficient to do so and leading to inappropriate conclusions being drawn (Benn and Evans, 2004).

This paper adopts a hierarchical approach to the interpretation of the glacial history of a single drainage basin. At the smallest scale, the individual sedimentary facies identified in the valley are described and interpreted. At a larger scale, the individual sediment-landform associations are described and alternative hypotheses for their formation evaluated in the light of the available evidence. Finally, the evidence is combined to develop a process-form model that represents the most likely history of glaciation in the valley and permits an assessment to be made of the wider significance of the study.

\section{ENNERDALE}

Ennerdale is a classic over-deepened glacial trough located in the western part of the English Lake District (Fig. 1), carved out of Ordovician volcanic rocks (the Borrowdale Volcanic Group) and late Caledonian granitic rocks (the Ennerdale Granophyre) in the upper part of the valley, and mudstone and sandstone of the Ordovician Skiddaw Group flanking the lake of Ennerdale Water. The central part of the Lake District is characterised by a generally radial pattern of glacial troughs, to which Ennerdale conforms, running approximately from the south-east to the northwest in its upper parts. The valley begins abruptly in the cliffs of Great Gable (899 
m), which dominate its head (Fig. 2). The upper valley is encircled by the peaks of Pillar (892 m) and Kirk Fell (802 m) to the southwest and Brandreth (715 m), Haystacks (582 m) and High Crag (704 m) to the northeast. The lower part of the valley is occupied by the glacially carved rock basin containing 4-km long Ennerdale Water, and shows a well-developed suite of landforms associated with the recession of the last (Devensian) British Ice Sheet to occupy the region (Huddart, 1967).

In common with many of the Lake District valleys, there is evidence that a valley glacier subsequently occupied the upper part of Ennerdale. Although there is no direct dating control, this glacier is assumed to be of Younger Dryas age by analogy with other valleys containing similar evidence, and for which dating control is available (Pennington, 1978). The Ennerdale moraines, which extend for about $3 \mathrm{~km}$ from the head of the valley, have attracted interest since the late 19th century, when Ward (1873) described them as 'perhaps the finest examples of [a] large series of moraines' in the Lake District (p. 427). Manley (1959) mapped a glacier in the upper part of Ennerdale and attributed it to the Younger Dryas, although the map was at a small scale and no geomorphological evidence was presented. The most detailed examination of the valley landforms was presented by Sissons (1980), who mapped a glacier on the basis of 'remarkable hummocky moraine' (p. 23). Sissons identified two suites of mounds on the northern valley side. Those lower down the valley (described here as the valley-side subdued ridges, $\mathrm{A}_{3}$ ) were described as 'smooth mounds of drift' (p.19), and were inferred to be of pre-Younger Dryas age. Those higher up the valley (described here as the valley-side moraine-mound complex, $\mathrm{A}_{2}$ ) are smaller with steeper faces, and were inferred to be of Younger Dryas age, although there is no direct dating control. The boundary between these zones is not 
clear and Sissons (1980) suggested that the Younger Dryas glacier may have modified the pre-existing landforms making the determination of the precise glacier margin problematic.

The glacier mapped by Sissons (1980) had an area of $1.28 \mathrm{~km}^{2}$, a volume of $0.049 \mathrm{~km}^{3}$ and a firn line elevation calculated to be $465 \mathrm{~m}$. The glacier has an anomalously low gradient in its terminal area when compared with others mapped from similar evidence in the Lake District. Sissons suggested that this may have been a result of surging, and the firn line derived for this glacier may therefore be too low, but no evidence was presented in support of this supposition.

\section{METHODS}

Geomorphological mapping was undertaken from aerial photographs and validated in the field. Structural mapping of the valley-side moraine-mound complex was undertaken by measuring the dip and direction of dip of the up-valley facing rectilinear faces and the orientation of the ridge crests. There are few extensive sedimentary exposures in the Ennerdale moraines, so it was not possible to observe the facies architecture of the landform-sediment associations. Observations were made, and clast and matrix samples taken, from all natural exposures encountered. The grain-size distribution of the matrix samples was determined by sieve and SediGraph 5100 analyses in the laboratory. Clast-roundness measurements were made using the Powers scale and plotted as histograms. Measurements of clast $a$-, $b$ - and $c$ axes were made with a ruler and clast shape data plotted on Sneed and Folk ternary diagrams (Sneed and Folk, 1958; Benn and Ballantyne, 1993), using the software of Graham and Midgley (2000a). Covariant plots of the $\mathrm{C}_{40}$ index (proportion of clasts 
with a c:a axial ratio of less than or equal to 0.4 ) and RA index (proportion of angular and very angular clasts) were used to aid discrimination of debris transport pathways (Benn and Ballantyne, 1994). The proportions of striated and faceted clasts were also noted. A digital elevation model was generated using total-station derived data.

\section{SEDIMENTARY FACIES}

\section{Lithofacies descriptions}

The physical properties of the lithofacies observed in upper Ennerdale are described below and summarised in Table 1 and Figure 3. The sampling locations are indicated on Figure 2.

Gravel $(G)$. This facies occurs in exposures throughout the study area. The clast and matrix characteristics of this facies form a continuum with the diamicton facies (D) described below and they are differentiated on the basis of texture.

Diamicton (D). This facies is similar in many respects to the gravel (G) facies and is found throughout the study area. It appears massive, although exposures rarely extend for more than a few metres.

Bedded sand and gravel (SGb). This facies occurs in a single small exposure in the valley-side moraine-mound complex. It occurs in association with the diamicton (D) facies, but the exposure is too limited to establish the relationship between the facies. The facies consists of predominantly coarse and very coarse sand and fine pebbles, with centimetre-scale bedding. Clasts are predominantly rounded and subrounded and have no facets or striations. 
Control sample: River channel (CS1). Examples of this facies were obtained from the River Liza by the footbridge and from Tongue Beck.

Control sample: Scree (CS2). This facies was collected from scree on the northern valley side, above the valley-side moraine-mound complex $\left(\mathrm{A}_{2}\right)$.

\section{Lithofacies interpretations}

\section{Gravel $(G)$ and diamicton $(D)$}

These facies are both interpreted predominantly as basally transported glacial sediment, the principal difference between them being the proportion of gravel. Unambiguous evidence that these facies have been subjected to traction-zone transport at the glacier bed is the presence of faceted and striated clasts (Boulton, 1978). The poorly sorted sediment, with significant proportions of fine particles in the matrix grain-size distribution, supports a subglacial origin and reflect crushing and abrasion at the glacier bed (Boulton, 1978; Kirkbride, 1995). All of the samples show peaks in clast roundness in the subangular class and intermediate $\mathrm{C}_{40}$ indices, commonly reported for subglacially transported sediment (Bennett et al., 1997). A covariant plot of the RA and $\mathrm{C}_{40}$ indices, on which it is impossible to separate the facies, provides support for a common interpretation for the gravel and diamicton facies (Fig. 3b). Both facies may be clearly differentiated from the fluvial and scree control samples. It is not possible to determine whether the sediments derived these characteristics from transport by a Younger Dryas glacier, or whether they represent reworked material from earlier glaciations. 
The bedded nature of the sediment, absence of fines and degree of sorting suggests a fluvial origin for this facies (Maizels, 1995). The small size of the exposure precluded the possibility of determining the nature of larger-scale structures within the deposit and it is not possible to determine a more specific origin.

\section{River channel samples (CS1)}

The fluvial samples are typical of mountain stream sediments. Most of the finegrained material has been removed, and the clasts are clearly distinguishable from the other facies by clast shape and roundness. The most likely source of the sediment is the moraines through which the streams flow, which are composed of gravel (G) and diamicton (D). The significant proportion of subangular clasts reflects this origin and suggests the sediment has been subjected to limited fluvial transport distances.

Scree samples (CS2)

These samples are typical of the Ennerdale scree deposits, two-thirds of the clasts being angular or very angular. However, the proportion of angular clasts is low compared with many active scree deposits. This probably represents edge-rounding during a prolonged period of weathering processes. The facies is clearly distinguishable from all of the other facies identified in Ennerdale on the basis of clast roundness and shape.

\section{Synthesis}

The sediments within the upper Ennerdale moraines appear to have been subject to active basal glacial transport, with some fluvial modification. There is little evidence 
of a significant passively transported component. These observations are consistent with the general topographic setting of upper Ennerdale, with few steep slopes capable of supplying significant volumes of supraglacial debris. The sedimentary evidence tends to support the hypothesis that the last glacier in upper Ennerdale was characterised by a warm-based thermal regime in which meltwater facilitated sliding over, and deformation of, the bed. However, the possibility that the sediments gained their physical properties during the previous glacial episode and were subjected to minimal modification during the last glacial period cannot be ruled out. Whichever is the case, the last glacier in upper Ennerdale apparently did not carry a significant supraglacial debris load.

\section{SEDIMENT-LANDFORM ASSOCIATIONS}

Four sediment-landform associations record the presence of a glacier in the upper part of Ennerdale.

\section{Sediment-landform association descriptions}

Oblique ridges on the Tongue $\left(A_{1}\right)$

A series of subparallel, generally subdued, ridges run obliquely down the south-west facing slope of the Tongue (Figs. 2 and 4a). Nine clear, fairly continuous, ridges can be identified on aerial photographs and from a distant vantage point (Fig. 4), but identification of individual ridges at close quarters in the field is difficult because the slope on which they are located is steep. The ridges appear to bifurcate in places and sometimes die out. Their height was estimated to be between $2 \mathrm{~m}$ and $4 \mathrm{~m}$. The ridges have a slightly asymmetric cross-profile, with a steeper down-valley face. 
Measurements from aerial photographs indicated that the ridges are generally oriented between $265^{\circ}$ and $085^{\circ}$. There are no sedimentary exposures in the ridges so determination of their constituent facies was not possible. Occasional, predominantly angular, blocks lie on the surface of the ridges.

\section{Valley-side moraine-mound complex $\left(A_{2}\right)$}

An extensive moraine-mound complex dominates the northern side of upper Ennerdale (Figs. 2 and 4b). Down valley, and higher up on the valley side, the complex has a diffuse boundary with the valley-side subdued ridges $\left(\mathrm{A}_{3}\right)$. The moraine-mound complex is separated from the valley-floor moraines $\left(\mathrm{A}_{4}\right)$ by the River Liza and Tongue Beck, although the forms immediately adjacent to the river are morphologically similar to the valley-floor moraines.

The moraine-mound complex consists of mounds and ridges rising up to $17 \mathrm{~m}$ from the surrounding topography (Fig. 5). The overall impression is of a complex morphology, but close examination reveals clear structure within the landformsediment association. The organisation is strongest immediately up-valley of the Youth Hostel, where chains of mounds form ridges up to $250 \mathrm{~m}$ long. The overall appearance of these ridges is akin to a string of beads, with the slight depressions in the long profile between each mound being well elevated above the surrounding topography (Fig. 5). Although the ridges formed by the chains of mounds are commonly continuous for considerable distances, it is also common for individual mounds to be offset from the trend of the ridge crest, and the ridges do not form an anastomosing network. The ridges are orientated sub-parallel to the long-axis of the valley, trending slightly towards its centre down-valley. With distance up-valley the 
organisation becomes increasingly chaotic, until distinct ridges can no longer be traced. Where the mounds and ridges are widely spaced, flat boggy ground lies between them. Bedrock is exposed between the mounds in several places, most extensively directly north of Tongue Beck where the mounds appear to lie directly on bedrock. Elsewhere, the proximity of bedrock to the surface could not be directly determined, but exposures between the mounds and in the bed of the River Liza indicate that bedrock is rarely at a depth of more than a few metres between the mounds.

Many of the mounds have rectilinear faces dipping predominantly towards the south (oblique to the valley side which dips to the southwest in this area). Of 74 mounds examined, $54(73 \%)$ had rectilinear faces. Slope dips ranged from $20^{\circ}$ to $38^{\circ}$ with a mean of $28^{\circ}$ (Fig. 6). The direction of dip of the rectilinear faces varies systematically through the moraine-mound complex. Whilst there is a considerable scatter, there is a general trend for the dips to be generally to the south in the downvalley part, turning towards the southwest in the up-valley part of the complex (the trend of the valley axis is southeast-northwest). This general trend is reflected in the strikes of the ridge crests (although the orientation of individual mounds is not always perpendicular to the dip of the rectilinear slopes), with the additional notable factor being an increase in variability up-valley. The north-facing sides of the mounds are generally irregular and rectilinear slopes are absent.

Exposures in the moraine mounds principally reveal the diamicton (D) facies, although the gravel $(\mathrm{G})$ facies is also represented. The bedded sand and gravel (SGb) facies occurs in a single exposure and is associated with the diamicton facies, but their 
geometrical relationship could not be established. No systematic spatial variations in the characteristics of the sediments could be determined. Angular boulders are abundant on the surface of the mounds.

\section{Valley-side subdued ridges $\left(A_{3}\right)$}

A series of subdued ridges are present on the valley side, down-valley of the valleyside moraine-mound complex. These ridges are clearly visible on aerial photographs and from a distance in the field, but are less easily identified close up. The landform association is most clear on the valley side beneath Scarth Gap (Fig. 2), but can also be identified in places on the valley side above the moraine-mound complex. As noted above, there is no clear boundary between the valley-side moraine-mound complex and the valley-side subdued ridges. However, they can be differentiated on the basis of: (i) their more subdued, whaleback, morphology; (ii) continuous ridge crests (breached occasionally by streams); (iii) absence of rectilinear faces; and (iv) consistently different ridge-crest orientations (Fig. 6).

Seven ridges, up to $200 \mathrm{~m}$ in length, are identifiable on the ground. The amplitude of the ridges is variable, but in the region of $50 \mathrm{~m}$, and they rise up to $6 \mathrm{~m}$ above the surrounding topography. Two small exposures reveal examples of the gravel (G) and diamicton (D) facies.

\section{Valley-floor moraine-mound complex $\left(A_{4}\right)$}

A moraine-mound complex is present on the floor of upper Ennerdale from below the Tongue to a little way into the conifer plantation (Figs. 2 and 4a). The moraine-mound complex consists of numerous mounds and short-crested ridges rising up to $4 \mathrm{~m}$ from 
the surrounding topography. The mounds commonly rise sharply from flat boggy ground and their true relief may be significantly larger than the apparent relief. The boundary between the oblique ridges on the Tongue $\left(\mathrm{A}_{1}\right)$ and the valley-floor moraine-mound complex is sharp (Fig. 4a), but it is unclear whether this is a result of a real difference in landform type, or infilling by sediment. In contrast, the boundary between the valley-floor $\left(\mathrm{A}_{4}\right)$ and valley-side $\left(\mathrm{A}_{2}\right)$ moraine-mound complexes is diffuse.

The morphology of the moraine-mound complex appears to be chaotic, the orientations and heights of individual mounds being inconsistent and their distribution irregular. However, on the southern side of the valley the complex appears to merge into a series of six small ridges (Fig. 2).

Exposures in the mounds themselves are limited to small fluvial and footpath scrapings. The sediments are predominantly diamictons (facies D), but the gravel (G) facies are also represented. Dispersed, predominantly angular, blocks lie on the surface of the mounds.

\section{Possible origins of the sediment-landform associations}

Many models have been proposed to explain the formation of British Younger Dryas moraines, and it is widely accepted that they are polygenetic in origin (Benn, 1996). These models fall into four classes:

(i) deformation of sediment at the glacier bed (e.g. Benn, 1992; Bennett, 1995); 
(ii) deposition at the glacier margin during active ice-margin recession (e.g. Benn, 1992; Bennett and Boulton, 1993b; Lukas, 2005);

(iii) deposition of englacial and supraglacial debris during ice stagnation (e.g. Eyles, 1983; Benn, 1992);

(iv) deposition of debris entrained along englacial thrusts (Hambrey et al., 1997; Bennett et al., 1998; Graham and Midgley, 2000b).

The key properties of these models, and their ability to explain the four glacial sediment-landform associations in Ennerdale, are now assessed.

\section{Subglacial deformation}

Bedforms may be formed beneath warm-based glaciers at a variety of spatial scales and are commonly associated with Scottish Younger Dryas glaciers (Benn, 1992; Bennett, 1995). They are commonly classified on the basis of their length and elongation ratio as flutes, megaflutes and drumlins (Rose, 1987). Constituent sediments are variable, reflecting the particular material over which the glacier flowed, but commonly consist of sheared basal till (Benn, 1992). Their morphology is highly varied and may reflect more than one glacial episode. They may be older landforms reworked by subglacial processes during subsequent glacier advances, or subglacial landforms submerged by supraglacial sediment during deglaciation (Bennett, 1995). However, typical bedforms have a low streamlined morphology oriented parallel to glacier flow. 
In upper Ennerdale, three of the sediment-landform associations are possible candidates for a subglacial origin. The valley-side subdued ridges $\left(\mathrm{A}_{3}\right)$ do not have the classic streamlined form associated with drumlins and flutes, but their whaleback morphology may result from the subglacial remoulding of earlier landforms. The sedimentology and gross morphology of the valley-side moraine-mound complex $\left(A_{2}\right)$ is consistent with a subglacial origin. Bedforms of this scale occur at contemporary glacier margins, but are generally smoothly streamlined and often taper down-glacier (Krüger and Thomsen, 1984). Relict subglacial features in Scotland are generally low and broad (Bennett, 1995). In Ennerdale, the sharp and undulating ridge crests, with offset peaks and common rectilinear faces, are difficult to explain using a subglacial deformation model.

The valley-floor moraine-mound complex $\left(\mathrm{A}_{4}\right)$ also lacks the classic streamlined morphology commonly associated with subglacial landforms. The inconsistent orientation of the ridge crests militates against a subglacial origin, although the constituent sediments are compatible with it.

\section{Active ice-margin recession}

Moraines form at active glacier margins by a variety of processes, the most common being dumping and washing of sediment from the glacier surface to form dump moraines and ice-contact fans, and the small-scale pushing and squeezing of sediment by the ice (Benn and Evans, 1998). The composition of ice-marginal moraines is highly variable, reflecting the transport history of the sediment and the method by which it was deposited. However, a number of common elements characterise the morphology of each of the ice-marginal moraine types. The plan-form of the moraines 
reflects that of the ice margin at which they formed and the spatial distribution of debris within the glacier (Bennett and Boulton, 1993a). The volume of sediment within the moraines reflects the balance between the sediment flux and the stability of the location of the ice margin (Bennett and Glasser, 1996). Chains of mounds are common along the frontal margins where the debris flux varies across the glacier margin. The relative stability of the lateral margins of glaciers is conducive to the formation of large dump moraines (Eyles, 1979; Small, 1983). Because they form over long periods, the morphology of lateral moraines is controlled by the location and gradient of the ice margin, and is insensitive to short-term variations in the spatial distribution of debris within the glacier.

As ice-marginal moraines tend to be reworked by glacier advances, and have little topographic expression when formed during continuous glacier recession, they are characteristic of punctuated ice-margin recession, with each moraine ridge representing the location of a still-stand or minor readvances (Evans, 2003b).

Bifurcating ridge crests are common where the rate of ice-margin recession is variable along the ice front. The cross-profile of ice-marginal moraines is strongly controlled by the depositional process. Where the moraines are ice-supported during deposition, ice-contact faces tend to rest at the angle of repose; however, they may be subject to considerable paraglacial reworking. Where ice-marginal pushing and squeezing is important, the ice-contact face is commonly gently dipping (Price, 1970). The distal faces of push and squeeze moraines tend to be steep, whilst ice-contact fans have comparatively gentle distal slopes (Lukas, 2005). 
In upper Ennerdale, all of the sediment-landform associations are potential candidates for an ice-marginal origin. The oblique ridges on the Tongue $\left(A_{1}\right)$ are subparallel and have anastomosing ridge crests, which are key diagnostic indicators of formation at an ice margin. Their valley-side location and orientation oblique to the axis of the valley also support an ice-marginal origin. The absence of sedimentary exposures in this sediment-landform association makes the determination of a more specific origin difficult.

The valley-side location and planform morphology of the valley-side subdued ridges $\left(A_{3}\right)$ is also consistent with an ice-marginal origin, but their precise origin is difficult to determine in the absence of good sedimentary exposure. Their comparatively subdued morphology (relative to the other sediment-landform associations in Ennerdale) suggests they may be older than the other landforms in the valley, or that they may have been overridden by a later glacier advance. Sissons (1980) argued that both were the case and that the diffuse boundary between the valley-side moraine-mound complex $\left(\mathrm{A}_{2}\right)$ and the subdued ridges may have resulted from modification of the latter by a Younger Dryas glacier. Without direct dating control, it is likely that the relative ages of these landforms will remain uncertain.

The valley-side moraine-mound complex bears some resemblance to the lateral dump moraines commonly associated with relatively high-relief mountain environments (Benn et al., 2003). Nested sets of moraines may record successive icemargin positions (Boulton and Eyles, 1979). Models of dump moraine formation in lateral positions stress the importance of the delivery of passively transported sediment from the glacier surface (Boulton and Eyles, 1979; Small, 1983). Whilst 
such moraines may contain significant proportions of passively transported sediment, particularly in more frontal positions (Matthews and Petch, 1982; Benn and Ballantyne, 1994), the proportion of passively transported sediment observed in the Ennerdale moraine-mound complex (as indicated by the proportion of angular and very angular clasts) are much lower than the proportions observed in Scottish Younger Dryas lateral moraines (Benn, 1989), and towards the lower end of the range observed at contemporary Norwegian glaciers (Matthews and Petch, 1982; Benn and Ballantyne, 1994). Futhermore, lateral moraines tend to reflect the planform morphology of the ice-margin and generally decrease in elevation in a down-glacier direction (Bennett and Glasser, 1996). These characteristics contrast with observations in Ennerdale, where the crest-lines of the moraines are undulating and individual mounds are commonly offset from the general trend-line of the ridge. Finally, although lateral moraines are commonly of considerably different sizes on opposite sides of a valley (e.g. Benn, 1989), they are generally expected to occur in pairs, one on each side of the valley. Although precise matching of the number of moraines on each side of a valley is often not possible, in upper Ennerdale moraines appear to be entirely absent on the southern side of the valley. Overall, these characteristics strongly suggest that the valley-side moraine-mound complex did not form as nested lateral dump moraines.

An alternative hypothesis is that the valley-side moraine-mound complex resulted from ice-marginal pushing and squeezing. This seems unlikely because such landforms commonly have shallow ice-proximal slopes and it is difficult to explain why the moraines should be so well developed on the northern side of the valley and absent elsewhere. It has recently been argued that the majority of Scottish moraine- 
mound complexes represent suites of nested ice-contact fans (Lukas, 2005). However, the shallow distal slopes associated with such features are in marked contrast to the steep distal slopes in the valley-side moraine-mound complex $\left(\mathrm{A}_{2}\right)$.

Groups of moraine mounds that have no clear organisation when viewed from the ground have been used by various workers to delimit former ice extent when their distribution is mapped from aerial photographs (e.g. Benn, 1992; Bennett, 1994; McDougall, 2001). In the case of the valley-floor moraine-mound complex $\left(\mathrm{A}_{4}\right)$, the distribution of mounds does not suggest an ice-marginal origin, except on the lower slopes of Kirk Fell where six sub-parallel ridges are present. The relation between these ridges, whose sub-parallel nature does indeed suggest an ice-marginal origin, and the remainder of the moraine-mound complex is unclear. It is possible that they actually represent the result of two distinct sets of processes.

\section{Ice stagnation}

Ice-stagnation describes the situation where ice no longer slides and deforms internally and may occur either when heavily debris-covered ice becomes dynamically separated from the main glacier body, or as a result of a decrease in surface gradient (e.g. following a surge or a period of negative mass balance). When stagnation occurs, any debris within the glacier cannot be delivered to the glacier margin and so is deposited in situ as the ice melts. This process may occur at a variety of scales, from complete glacier tongues, through narrow debris-covered bands close to the glacier margin (Eyles, 1983), to the melting of small cores of ice trapped beneath sediment (Benn, 1992). During deposition, the sediment is commonly subject to repeated remobilisation as the surface topography varies as a result of differential 
ablation and may result in topographic inversion (Eyles, 1979). The resulting sediment-landform association (ablation moraine) is commonly characterised by a chaotic morphology with little or no discernable structure, although marked spatial variations in debris concentration may be weakly preserved in the resulting moraine morphology (Boulton, 1972; Benn and Evans, 1998). The nature of the constituent sediments is extremely diverse and depends on both their transport history and the process by which they were deposited. The structures within the sediments commonly reflect the importance of water in re-distributing the sediment. Typical sediments include those associated with debris flows, meltwater streams and resedimentation into small water bodies, and there may be evidence of deformation structures (Boulton, 1972; Eyles, 1979).

In upper Ennerdale, both the valley-side $\left(\mathrm{A}_{2}\right)$ and valley-floor $\left(\mathrm{A}_{4}\right)$ morainemound complexes are possible candidates for an ice-stagnation origin. The clear morphological structure within the other sediment-landform associations militates against a stagnation origin. The apparently chaotic morphology of the valley-floor moraine-mound complex $\left(\mathrm{A}_{4}\right)$ is entirely consistent with a stagnation origin, although the close association with the six sub-parallel ridges on the slopes below Kirk Fell suggests that there may be some morphological organisation within the complex that is concealed beneath the boggy sediments between them. The constituent sediments are poorly exposed so the internal structure of individual mounds cannot be determined. Where they are exposed, the constituent sediments are interpreted to have been subject to subglacial transport. This does not preclude an ice-stagnation origin for the mounds, but requires that the sediment was elevated into the body of the glacier prior to deposition. 
The valley-side moraine-mound complex $\left(\mathrm{A}_{2}\right)$ has a much stronger spatial organisation than that on the valley floor. This is not inconsistent with an icestagnation origin and may be explained by the distribution of debris septa within the glacier. However, such structure is generally weakly preserved after deglaciation (Benn and Evans, 1998), and the overall topography would be exceptional for a stagnation origin. In particular, it is difficult to explain the presence of systematically orientated rectilinear faces on many of the mounds. Nevertheless, the presence of bedded sand and gravel within one exposure is entirely consistent with the remobilisation processes that are commonly associated with the formation of ablation moraine. As for the valley-floor moraines, if formation of these moraines was associated with ice-stagnation processes, the basally transported sediment that appears to be their most common constituent would have required elevation into the body of the glacier so that ice could be trapped beneath it.

\section{Englacial thrusting}

Thrusting is a common process in the lower reaches of glaciers where they are subjected to longitudinal flow compression, and is particularly widespread in glaciers of polythermal character. In Svalbard polythermal glaciers, thrusting takes place at the ice margin, englacially and even proglacially, especially when the glacier is dynamic and advancing. Entrainment of large volumes of subglacial or basal glacial debris accompanies this process (Hambrey et al., 1997; Hambrey et al., 1999; Bennett, 2001; Glasser and Hambrey, 2001). Ice-marginal thrusting involving substantial volumes of debris has also been documented in temperate Icelandic glaciers, and locally in alpine temperate glaciers (Goodsell et al., 2005). Release of the debris produces moraine- 
mound complexes that maintain their integrity in zones of permafrost, albeit modified by slope processes (Hambrey and Huddart, 1995; Huddart and Hambrey, 1996; Bennett et al., 1999).

The resulting moraine complexes consist of consistently aligned, imbricate, mounds and ridges. The form of individual moraines is variable, ranging from ridges up to hundreds of metres long to almost conical mounds; most are a few metres in height (Bennett et al., 1998). Rectilinear faces, typically dipping at $30^{\circ}$, are characteristic of the ice-proximal faces and represent the geometry of the original thrust plane. Distal faces are often steeper and irregular, resting at the angle of repose. Thrust-moraine complexes may contain a diverse range of sediment types, reflecting the material over which the glacier flowed. Individual ridges are commonly composed of a single facies or facies association, but may be stacked on another ridge with a quite different character (Glasser and Hambrey, 2003). The ultimate morphology of the moraines following climatic amelioration is strongly controlled by their constituent sediments. Mud-rich moraines tend to be remobilised as gravity-driven flows, whilst thick wedges of well-drained sediments tend to preserve the thrust geometry (Graham, 2002). Bennett et al. (1996b) argued that the final morphology is also dependent on the spacing of thrusts. Where thrusts are closely spaced, there is little disruption to the sediment slabs during deglaciation; where thrusts are widely spaced, slumping and settlement is likely as the ice between them melts. Thus englacial thrust-moraines can be seen as one end of a continuum between thrustcontrolled and ablation moraines. 
In upper Ennerdale, the valley-floor $\left(\mathrm{A}_{4}\right)$ and valley-side $\left(\mathrm{A}_{2}\right)$ moraine-mound complexes are potential candidates for a thrust origin, but not necessarily of the Svalbard polythermal type. The broad belt of moraine mounds of variable size, combined with the presence of rectilinear faces with a consistent dip and orientation on the southern side of many of the mounds, is very similar to the morphology of contemporary thrust-moraine complexes. Furthermore, the overall appearance of the moraine-mound complex is suggestive of slabs of sediment that are imbricately stacked upon one another, a relation that is particularly clearly shown in Fig. 4c. Although the evidence of the constituent facies and internal geometry of the moraines in Ennerdale is limited, the presence of sediment inferred to be of basal origin and bedded sands and gravels is consistent with formation by englacial thrusting.

The valley-floor moraine-mound complex $\left(\mathrm{A}_{4}\right)$ lacks most of the indicators of a thrust origin (such as rectilinear faces and imbricate structure). However, it is still possible that the moraines have a thrust origin, but that the thrusts were widely spaced and the structure has been destroyed by resedimentation during deglaciation. This supposition is supported by the relatively sparse distribution of the mounds, as well as the transitional nature of the boundary with the valley-side moraine-mound complex with its more typical thrust-moraine morphology.

\section{Synthesis}

Based on an evaluation of the strength of the evidence for each of the different models for moraine formation, Table 2 synthesises the likely origins of each sedimentlandform association treated in isolation. 
It is fairly clear that the oblique ridges $\left(A_{1}\right)$ and valley-side subdued ridges $\left(A_{3}\right)$ represent ice-marginal positions, although the lack of detailed sedimentological evidence has precluded the determination of a more precise origin. The subdued ridges may have obtained their subdued morphology as a result of overriding by a subsequent glacier advance. The origin of the other landforms is more equivocal. Whilst both ice-stagnation and subglacial deformation are possible origins for the valley-side moraine-mound complex $\left(\mathrm{A}_{2}\right)$, the evidence is weak. An origin as lateral dump moraines is also possible, but it is difficult to explain the undulating nature of the ridge crests and the total absence of equivalent features on the opposite side of the valley. The support for an englacial thrust origin is not overwhelming, but this hypothesis best fits the available evidence.

Several hypotheses are able to explain the character of the valley-floor moraine-mound complex $\left(\mathrm{A}_{4}\right)$. A subglacial origin is possible, but considered unlikely. The available evidence is unable to distinguish between the ice-stagnation and englacial thrusting origin. Given the other evidence (such as ice-marginal moraines) for active deglaciation in upper Ennerdale, it seems unlikely that the valleyfloor moraines were associated with large-scale ice-stagnation processes, but localised stagnation cannot be ruled out. The close association and diffuse boundary between the valley-floor and valley-side moraine-mound complexes suggests that they may be genetically related, and lends support to a thrust origin for the valley-floor deposits.

\section{DISCUSSION}

\section{Englacial thrusting: a valid mechanism of landform genesis?}


Landforms interpreted as relict englacial thrust moraines have now been described in Glen Torridon, Scottish Highlands (Bennett et al., 1998), Cwm Idwal, north Wales (Graham and Midgley, 2000b), and Ennerdale. Although an englacial thrusting origin appears to provide the best fit to the available evidence at each of these sites, a number of workers have disputed the validity of this mechanism in the context of the British Younger Dryas landform record. The origin of the Glen Torridon landforms was disputed by Wilson and Evans (2000), who argued that the landforms represent subglacial bedforms that have been partially reworked from former ice-marginal landforms. However, none of the detailed evidence presented by Bennett et al. (1998) in support of an englacial thrust origin was addressed. Indeed, the majority of the evidence that Wilson and Evans (2000) presented is entirely consistent with a thrust origin for the landforms. The only exception is a map of the supposed bed forms, apparently based on aerial photograph interpretation, but there seems little evidence to support a subglacial origin in the images.

Most recently, Lukas (2005) argued, on the basis of detailed sedimentological investigations in the far northwest of Scotland, that Younger Dryas moraine-mound complexes were predominantly formed as a series of nested ice-contact fans. This interpretation is not disputed for these sites. However, the absence of evidence for thrusting at these sites does not mean that thrusting is not a valid mechanism for moraine-mound formation elsewhere (Graham et al., submitted). It has never been proposed that a thrusting origin for moraine-mound complexes is universal, or even particularly common. Indeed, as outlined in the following section, it seems likely that its applicability is restricted to a small number of sites in Britain where very specific conditions prevailed. It is clear that the thrusting model does not fit either the 
morphology or sedimentology described by Lukas (2005). Most notably, his description of low-angle ice-distal faces is in marked contrast to the steep distal faces, at the angle of repose, seen at all of the sites where thrusting has been proposed.

\section{The significance of thrust-moraine formation in upper Ennerdale}

If the inference that englacial thrusting was responsible for generating some of the sediment-landform associations in upper Ennerdale is correct, the formation and longterm preservation of these landforms has a number of significant implications.

Mapping of thrust-traces on the surfaces of Svalbard glaciers reveals that most thrusts form approximately parallel to the ice-margin, that is perpendicular to the direction of maximum compressive stress (e.g. Hambrey et al., 1999). In Svalbard thrust-moraines, the rectilinear face of each mound appears to record the geometry of the thrust from which the constituent sediment was deposited, and plotting the direction in which these faces dip provides evidence of the direction of maximum local compressive stress in the glacier. A structural map of the rectilinear faces in the Ennerdale valley-side moraine-mound complex suggests a variation in maximum compressive stress from the south in the down-valley part of the moraine-mound complex to the south-west further up-valley (Fig. 6). This pattern of stress is strongly suggestive of ice flow into and across Ennerdale from Kirk Fell. McDougall (2001) mapped a Younger Dryas plateau icefield on the summit of Kirk Fell with an outflow glacier entering Ennerdale via Baysoar Slack cirque. Alternatively, a cirque glacier may have formed in Baysoar Slack and been nourished by snow blown from the plateau surface to the south. Additional lines of evidence supporting ice-flow from Kirk Fell are the subdued ridges running up the southern valley-side, which are likely 
to represent ice-marginal positions. The supposition that a glacier flowed from Kirk Fell also helps to explain the apparently anomalous low gradient of the terminus of the Ennerdale glacier noted by Sissons (1980).

The initiation of thrusting in glacier ice results from longitudinal flow compression that cannot be absorbed by ductile deformation (Bennett et al., 1996b; 1999). In Svalbard polythermal glaciers, this compression results from the transition between warm- and cold-based ice, but a number of other factors may also result in compression. All of the British Younger Dryas thrust moraines so far inferred are stacked against the valley side, and it seems likely that their formation was strongly influenced by compression against a reverse bedrock slope. In Ennerdale, the oblique ridges on the Tongue provide evidence that ice was present in the upper part of Ennerdale, immediately below the slopes of Great Gable, and it seems reasonable to infer that the confluence of ice from Kirk Fell and Great Gable may also have been a contributory factor in generating compressive stresses great enough to initiate thrusting.

It is worthwhile also considering the circumstances in Ennerdale for the thrust moraines to be preserved in the landform record. The preservation of a distinctive thrust-moraine morphology in the landform record requires limited syn- and postdepositional mass movement. Where significant volumes of buried ice are incorporated into the moraines during deposition, the ultimate morphology may be expected to reflect the processes of resedimentation, so the glaciotectonic structure is most likely to be preserved where the volume of sediment in thrusts is large compared with their spacing (Bennett et al., 1996b). If the valley-floor moraine-mound complex 
was formed from thrust sediment, the lower compressive stresses further away from the valley side may have produced fewer, and more widely spaced, thrusts and explain the poorly preserved tectonic structure. Steeply dipping thrusts also favour preservation as it is the base of the thrust which forms the mound and in steep thrusts more material is left in the base of the mound and less ice is draped with sediment, promoting resedimentation (Bennett et al., 1999). The location of the valley-side moraine-mound complex on well-drained ground away from the valley floor may also have aided its preservation.

Thrusting in Svalbard glaciers is commonly associated with polythermal ice. There is no direct evidence for this in upper Ennerdale, but the formation of thrustmoraines requires that significant quantities of sediment be entrained along englacial thrusts, and a polythermal basal regime may help to explain how this occurred. Whilst warm- and cold-based glaciers tend to have low basal-debris loads (e.g. Chinn and Dillon, 1987; Kirkbride, 1995), polythermal glaciers may develop very thick, debrisrich, basal ice-layers (in excess of 15 m, e.g. Lawson, 1979). However, such thick layers are associated with glaciers several orders of magnitude larger than that in upper Ennerdale (Kirkbride, 1995). Given the limited distance available for a debrisrich basal ice-layer to form, it is unlikely that sufficient debris could have been entrained in the basal ice-layer to explain the volume of sediment observed in each mound in Ennerdale. Subglacial sediment must, therefore, have been the source for the moraines. The presence of bedrock exposures between the moraine mounds suggests that the sediment-bedrock interface may have acted as a décollement surface, enabling rafts of subglacial debris to be elevated into the glacier. The debris loads of thrusts in warm-based glaciers tend to be much lower than in polythermal 
glaciers, although there have been few structural studies of non-surge-type warmbased glaciers. It has been suggested that this difference reflects a combination of the freezing-on of rafts of sediment at the thermal boundary and a corresponding increase in longitudinal compression associated with a change from sliding to non-sliding conditions (Hambrey and Huddart, 1995; Bennett, 2001). Therefore, there is some prima facie evidence that the entrainment of large volumes of sediment in upper Ennerdale may have been associated with polythermal ice.

\section{A process-form model for upper Ennerdale}

In the light of the preceding discussion, and the documentation of the morphology and sedimentology of the landform-sediment associations in Ennerdale, it is possible to propose a process-form model for the Younger Dryas glaciation in the upper valley.

A few thousand years after the complete withdrawal of ice following the Last Glacial Maximum, glaciers became re-established on the Central Fells of the Lake District, including the crags and cirques of Great Gable and Kirk Fell. Ice flowed into and along Ennerdale from these source areas. The maximum extent of the Ennerdale glacier is uncertain, but its limit is likely to be marked by the furthest of the subdued ridges on the northern valley-side. The limit may be obscured within what is currently forested land.

The flow of ice from Kirk Fell across Ennerdale, and its confluence with the main Ennerdale glacier, resulted in longitudinal compression against the northern valley side and the initiation of thrusting within the glacier ice. Debris was entrained along these thrusts and elevated into the body of the glacier. During the subsequent 
retreat of the glacier, the sediment in these thrusts was lowered onto the valley side, the geometry of the thrust plane being reflected by the dip of the rectilinear slopes of the resulting sediment mounds. The moraine-mound complex formed by this process is likely to reflect thrusting that occurred towards the end of the Younger Dryas glaciation as the influence of the main Ennerdale glacier declined, otherwise the structure would have been modified or destroyed. This also explains why ice-marginal moraines do not overprint or disrupt the pattern, and provides evidence that the recession of the glacier was dynamic during this phase.

The subsequent retreat history of the Ennerdale and Kirk Fell glaciers is uncertain because of the equivocal origin of the valley-floor moraine-mound complex $\left(\mathrm{A}_{4}\right)$. In addition, the small, probably ice-marginal, ridges associated with the valleyfloor moraine-mound complex $\left(\mathrm{A}_{4}\right)$ suggest dynamic recession, but their location and orientation makes it unclear whether they are related to the main Ennerdale or Kirk Fell glacier. If the valley-floor moraine-mound complex represents a stagnation deposit, this may have resulted from the recession of the Kirk Fell glacier. The very low gradient of the lower part of the main Ennerdale glacier was supported by the ice supplied by the Kirk Fell glacier. If this ice supply ceased, the low gradient ice on the floor of the valley may have become dynamically separated from the rest of the main Ennerdale glacier and stagnated in situ. If this is the case, no climatic significance can be attached to the stagnation deposit. Alternatively, the complex may provide no evidence about the nature of recession and may be formed of englacially thrust material, the original tectonic structure of which has been disrupted by subsequent glacier flow or reworking during deposition. Whatever the nature of this stage of the recession, the oblique ridges on the Tongue $\left(\mathrm{A}_{1}\right)$ appear to record a series of ice- 
marginal positions of the main Ennerdale glacier, suggesting that the final recession of this glacier was dynamic.

\section{Comparison with Cwm Idwal, North Wales}

There is a striking similarity between the topographic setting and sediment-landform associations developed in Ennerdale and those described by Graham \& Midgley (2000b) in Cwm Idwal, north Wales. Both sites have: (i) a moraine-mound complex with clear organisation stacked on the valley side; (ii) a more chaotically organised moraine-mound complex on the valley floor; (iii) no clear downvalley ice limits; (iv) a potential glacier source area on the opposite side of the valley to the moraine-mound complexes; and (v) small subparallel ridges beneath the potential source area. This remarkable similarity suggests that the process-form model developed for upper Ennerdale may be more generally applicable at sites where a perhaps extremely dynamic glacier, with its source high on a valley side, is confluent with a glacier at a relatively low altitude in the valley bottom.

\section{Wider significance}

The pattern of landform-sediment associations in upper Ennerdale contrasts sharply with the 'glaciated-valley landsystem' model first proposed by Boulton and Eyles (1979). This model is characterised by large volumes of passively transported sediment and the dominant sediment-landform association is large latero-frontal dump moraines. Benn and Evans (1998) distinguished between high- and low-relief glaciated-valley landsystems, with the principal difference being the magnitude of the debris supply from the valley sides. The model of Boulton and Eyles (1979) is 
appropriate for some tectonically active, high-relief, environments with large fluxes of passively transported sediment, whereas the model developed for upper Ennerdale (and also for Cwm Idwal) may provide an alternative glaciated-valley landsystem for tectonically stable, low-relief, mountain environments in which active transport dominates. The particular suite of sediment-landform associations developed at these sites may be expected where there is a strong cross-valley compressive stress regime.

The recognition of thrust-moraine complexes in the palaeo-landform record is of importance as it has potential implications for the reconstruction of glacier dynamics and palaeoclimate (Hambrey et al., 1997; Bennett et al., 1998; Hambrey and Glasser, 2002). In the case of Ennerdale it appears that the palaeoclimatic implications are limited, as the presence of a reverse bedrock slope and glacier confluence are likely to have been the dominant control on thrusting. The preservation of a glaciotectonic structure does, however, demonstrate that glacier retreat was dynamic and not dominated by in situ stagnation and associated resedimentation. Because they form englacially, thrust-moraine complexes do not provide direct evidence of the position of the ice-margin. Where an ice-marginal position has been inferred from the distribution of moraine-mound complexes, as has often been the case in the reconstruction of British Younger Dryas glaciers (e.g. Sissons, 1980; Gray, 1982), the maximum size of the glacier may be underestimated.

Although the deformation structures present in glacier ice are relatively well understood, the rôle of glacier ice-deformation in landform development has, until recently, been little studied. Recent work on contemporary glaciers in Svalbard (Bennett and Glasser, 1996; Bennett et al., 1996a; 1999; Hambrey et al., 1997; 1999) 
has begun to redress this, but work on evidence of ice-deformation associated with valley glaciers in the palaeo-landform record has hardly begun. In the British Younger Dryas landform record, evidence of ice-deformation is limited to the moraine-mound complex interpreted as thrust-moraines in Torridon, Scotland (Bennett et al., 1998; Wilson and Evans, 2000), Ennerdale and Cwm Idwal (Graham and Midgley, 2000b), and some sedimentological evidence of debris elevation in the morainic sediments on Skye, Scotland (Benn, 1990). Although such landforms are apparently not abundant, it seems likely that if three englacial thrust-moraine complexes are present in the British Younger Dryas landform record, others remain to be discovered. Similar structures have recently been identified in Pleistocene glacigenic sediments in Poland (Ruszczynska-Szenajch, 2001). With the exception of this Polish work, englacial thrust-moraine complexes in the palaeo-landform record have thus far only been recognised in association with cirque and valley glaciers, but there is no reason to believe they may not have formed elsewhere close to the margins of the Pleistocene ice-sheets where hummocky topography is common (e.g. Sollid and Sørbel, 1988; Johnson et al., 1995; Andersson, 1998; Eyles et al., 1999). Where they do exist, however, their recognition may be problematic because of degradation of the glaciotectonic structure. It is also likely that landforms resulting from other forms of ice-deformation, such as foliation-parallel ridges and supraglacial debris stripes, may await discovery in the palaeo-landform record (Hambrey and Glasser, 2002).

\section{CONCLUSIONS}

The typical Lake District glacial trough of Ennerdale contains one of the finest moraine-mound ('hummocky moraine') complexes in England. Inferred to date from 
the Younger Dryas or Loch Lomond Stade, the complex provides evidence of a multiplicity of events and a range of glaciotectonic and sedimentary processes. These processes, whilst not necessarily common in Britain, indicate that for certain combinations of glacier dynamics, thermal regime and topography, englacial thrusting is an important process in landform development. More specifically, it is concluded that:

(1) Four distinct landform-sediment associations record the presence of a glacier in the upper part of Ennerdale during the Younger Dryas. Ridges run obliquely down an elevated area (the Tongue) in the upper part of the valley. Moraine-mound complexes are developed on the northern valley-side and the floor of the valley. Subdued ridges run down the northern valley-side beyond the moraine-mound complex.

(2) The principal sedimentary facies that make up the landforms are gravel and diamicton, interpreted as basal till, and bedded sand and gravel, inferred to be the product of fluvial reworking.

(3) Ice-marginal moraines indicate that the recession of the glacier was predominantly active, although the presence of a chaotic moraine-mound complex on the valley floor suggests that ice may have stagnated locally because of dynamic separation of a subsidiary glacier from the tongue of the main Ennerdale glacier.

(4) There is good morphological and structural evidence that debris was entrained along thrusts within the body of a glacier that crossed the valley at right angles to its main axis, and resulted in the deposition of a distinctive sediment-landform association. Although polythermal ice is not ruled out, the principal contributing 
factors to thrusting are a glacier confluence and a reverse bedrock slope, which led to strong longitudinal compression in the ice. Although the inferred subsidiary glacier, originating on Kirk Fell, had previously been placed on a map, this work provides the first published evidence supporting the existence of such a glacier.

(5) The thrust-related sediment-landform association in Ennerdale is mirrored by that in Cwm Idwal, Wales. In both cases, a major source area for ice is located along the flanks of the valley. Similar topographic situations occur elsewhere in the British Uplands, so it is to be expected that there is scope for discovering other examples.

(6) This investigation highlights the importance of sediment, morphology and structure of moraines in establishing the style of glaciation in upland areas, and illustrates the care needed in inferring ice dynamics, glacier thermal regime, and ice limits.

\section{ACKNOWLEDGEMENTS}

This work was undertaken whilst D.G. was in receipt of a University of Wales, Aberystwyth postgraduate studentship. Permission to work at the site was granted by the Forestry Commission and the National Trust. Nicholas Midgley and Phillippa Noble provided field assistance. The authors thank David Huddart and an anonymous referee for their helpful and constructive comments.

\section{REFERENCES}

Andersson, G. (1998) Genesis of hummocky moraine in the Bolen area, southwestern Sweden. Boreas, 27, 55-67. 
Benn, D.I. (1989) Debris transport by Loch Lomond Readvance glaciers in Northern Scotland: basin form and the within-valley asymmetry of lateral moraines. J. Quatern. Sci., 4, 243-254.

Benn, D.I. (1990) Scottish Lateglacial Moraines: Debris Supply, Genesis and Significance. Unpublished $\mathrm{PhD}$ thesis, University of St. Andrews.

Benn, D.I. (1992) The genesis and significance of 'hummocky moraine': evidence from the Isle of Skye, Scotland. Quatern. Sci. Rev., 11, 781-799.

Benn, D.I. (1996) Glacial sedimentological research in Scotland. Scot. Geogr. Mag., $112,57-62$.

Benn, D.I. and Ballantyne, C.K. (1993) The description and representation of particle shape. Earth Surf. Proc. Land., 18, 665-672.

Benn, D.I. and Ballantyne, C.K. (1994) Reconstructing the transport history of glaciogenic sediments - a new approach based on the co-variance of clast form indices. Sed. Geol., 91, 215-227.

Benn, D.I. and Evans, D.J.A. (1998) Glaciers and Glaciation. Arnold, London, 734 pp.

Benn, D.I. and Evans, D.J.A. (2004) Introduction and rationale. In: A Practical Guide to the Study of Glacial Sediments (Eds D.J.A. Evans and D.I. Benn), pp. 1-10. Arnold, London. 
Benn, D.I., Kirkbride, M.P., Owen, L.A. and Brazier, V. (2003) Glaciated valley landsystems. In: Glacial Landsystems (Ed. D.J.A. Evans), pp. 372-406. Arnold, London.

Bennett, M.R. (1991) Scottish "Hummocky Moraine": its Implications for the Deglaciation of the North West Highlands During the Younger Dryas or Loch Lomond Stadial. Unpublished PhD thesis, University of Edinburgh.

Bennett, M.R. (1994) Morphological evidence as a guide to deglaciation following the Loch Lomond Readvance: a review of research approaches and models. Scot. Geogr. Mag., 110, 24-32.

Bennett, M.R. (1995) The morphology of glacially fluted terrain: examples from the Northwest Highlands of Scotland. Proc. Geol. Assoc., 106, 27-38.

Bennett, M.R. (2001) The morphology, structural evolution and significance of push moraines. Earth-Sci. Rev., 53, 197-236.

Bennett, M.R. and Boulton, G.S. (1993a) Deglaciation of the Younger Dryas or Loch Lomond Stadial ice-field in the Northern Highlands, Scotland. J. Quatern. Sci., 8, 133-145.

Bennett, M.R. and Boulton, G.S. (1993b) A reinterpretation of Scottish 'hummocky moraine' and its significance for the deglaciation of the Scottish Highlands during the Younger Dryas or Loch Lomond Stadial. Geol. Mag., 130, 301-318.

Bennett, M.R. and Glasser, N.F. (1996) Glacial Geology: Ice Sheets and Landforms. Wiley, Chichester, 
Bennett, M.R., Hambrey, M.J. and Huddart, D. (1997) Modification of clast shape in High-Arctic environments. J. Sed. Res., 67, 550-559.

Bennett, M.R., Hambrey, M.J., Huddart, D. and Ghienne, J.F. (1996a) The formation of a geometrical ridge network by the surge-type glacier Kongsvegen, Svalbard. J. Quatern. Sci., 11, 437-449.

Bennett, M.R., Hambrey, M.J., Huddart, D. and Glasser, N.F. (1998) Glacial thrusting and moraine-mound formation in Svalbard and Britain: the example of Coire a' Cheund-chnoic (Valley of a Hundred Hills), Torridon, Scotland. In: Mountain Glaciation (Ed. L.A. Owen), pp. 17-34. Wiley \& Sons, Chichester.

Bennett, M.R., Hambrey, M.J., Huddart, D., Glasser, N.F. and Crawford, K. (1999) The landform and sediment assemblage produced by a tidewater glacier surge in Kongsfjorden, Svalbard. Quatern. Sci. Rev., 18, 1213-1246.

Bennett, M.R., Huddart, D., Hambrey, M.J. and Ghienne, J.F. (1996b) Moraine development at the High-Arctic glacier Pedersenbreen, Svalbard. Geogr. Ann., 78A, 209-222.

Boulton, G.S. (1972) Modern Arctic glaciers as depositional models for former ice sheets. J. Geol. Soc. London, 128, 361-393.

Boulton, G.S. (1978) Boulder shapes and grain-size distributions of debris as indicators of transport paths through a glacier and till genesis. Sedimentology, 25, 773-799. 
Boulton, G.S. and Eyles, N. (1979) Sedimentation by valley glaciers: a model and genetic classification. In: Moraines and Varves (Ed. C. Schlüchter), pp. 11-23. Balkema, Rotterdam.

Charlesworth, J.K. (1956) The late-glacial history of the Highlands and Islands of Scotland. Trans. Roy. Soc. Edinb., 62, 103-929.

Chinn, T.J.H. and Dillon, A. (1987) Observations on a debris-covered polar glacier "Whiskey Glacier", James Ross Island, Antarctic Peninsula, Antarctica. J. Glaciol., 33, 300-310.

Evans, D.J.A. (2003a) Glacial Landsystems. Hodder Arnold, London, 532 pp.

Evans, D.J.A. (2003b) Ice-marginal terrestrial landsystems: active temperate glacier margins. In: Glacial Landsystems (Ed. D.J.A. Evans), pp. 12-43. Arnold, London.

Eyles, N. (1979) Facies of supraglacial sedimentation on Icelandic and Alpine temperate glaciers. Can. J. Earth Sci., 16, 1341-1361.

Eyles, N. (1983) Modern Icelandic glaciers as depositional models for 'hummocky moraine' in the Scottish Highlands. In: Tills and Related Deposits (Eds E.B. Eversen, C. Schlüchter and J. Rabassa), pp. 47-60. Balkema, Rotterdam.

Eyles, N., Boyce, J.I. and Barendregt, R.W. (1999) Hummocky moraine: sedimentary record of stagnant Laurentide Ice Sheet lobes resting on soft beds. Sed. Geol., 123, 163-174. 
Glasser, N.F. and Hambrey, M.J. (2001) Styles of sedimentation beneath Svalbard valley glaciers under changing dynamic and thermal regimes. J. Geol. Soc. London, 158, 697-707.

Glasser, N.F. and Hambrey, M.J. (2003) Ice-marginal terrestrial landsystems: Svalbard polythermal glaciers. In: Glacial Landsystems (Ed. D.J.A. Evans), pp. 65-88. Arnold, London.

Goodsell, B., Hambrey, M.J. and Glasser, N.F. (2005) Debris transport in a temperate valley glacier: Haut Glacier d'Arolla, Valais, Switzerland. J. Glaciol., 51, 139-146.

Graham, D.J. (2002) Moraine-mound formation during the Younger Dryas in Britain and the Neoglacial in Svalbard. Unpublished PhD thesis, University of Wales, Aberystwyth.

Graham, D.J., Bennett, M.R., Glasser, N.F., Hambrey, M.J., Huddart, D. and Midgley, N.G. (submitted) Comment on: "A test of the englacial thrusting hypothesis of 'hummocky' moraine formation". Boreas.

Graham, D.J. and Midgley, N.G. (2000a) Graphical representation of particle shape using triangular diagrams: an Excel spreadsheet method. Earth Surf. Proc. Land., 25, 1473-1477.

Graham, D.J. and Midgley, N.G. (2000b) Moraine-mound formation by englacial thrusting: the Younger Dryas moraine of Cwm Idwal, North Wales. In: Deformation 
of Glacial Materials (Eds A.J. Maltman, M.J. Hambrey and B. Hubbard), pp. 321336. Geological Society, London.

Gray, J.M. (1982) The last glaciers (Loch Lomond Advance) in Snowdonia, North Wales. Geol. J., 17, 111-133.

Hambrey, M.J., Bennett, M.R., Dowdeswell, J.A., Glasser, N.F. and Huddart, D. (1999) Debris entrainment and transfer in polythermal valley glaciers. J. Glaciol., 45, 69-86.

Hambrey, M.J. and Glasser, N.F. (2002) Development of landform and sediment assemblages at maritime High-Arctic glaciers. In: Landscapes of Transition: Landform Assemblages and Transformations in Cold Regions (Eds K. Hewitt, M. Byrne, M. English and G. Young), pp. 11-42. Kluwer, Dordrecht.

Hambrey, M.J. and Huddart, D. (1995) Englacial and proglacial glaciotectonic processes at the snout of a thermally complex glacier in Svalbard. J. Quatern. Sci., 10, 313-326.

Hambrey, M.J., Huddart, D., Bennett, M.R. and Glasser, N.F. (1997) Genesis of "hummocky moraines" by thrusting in glacier ice: evidence from Svalbard and Britain. J. Geol. Soc. London, 154, 623-632.

Huddart, D. (1967) The deglaciation of the Ennerdale area: a re-interpretation. Proc. Cumberland Geol. Soc., 2, 63-75. 
Huddart, D. and Hambrey, M.J. (1996) Sedimentary and tectonic development of a high-arctic thrust-moraine complex: Comfortlessbreen, Svalbard. Boreas, 25, 227 243.

Johnson, M.D., Mickelsen, D.M., Clayton, L. and Attig, J.W. (1995) Composition and genesis of glacial hummocks, western Wisconsin, USA. Boreas, 24, 97-116.

Kirkbride, M.P. (1995) Processes of transportation. In: Modern Glacial Environments: Processes, Dynamics and Sediments (Ed. J. Menzies), pp. 261-308. Butterworth-Heinemann, Oxford.

Krüger, J. and Thomsen, H.H. (1984) Morphology, stratigraphy, and genesis of small drumlins in front of the glacier Mýdalsjökull, south Iceland. J. Glaciol., 30, 94105.

Lawson, D.E. (1979) Sedimentological analysis of the western margin of Matanuska Glacier, Alaska. Cold Regions Research and Engineering Laboratory, Hanover, New Hampshire, 122 pp.

Lukas, S. (2005) A test of the englacial thrusting hypothesis of 'hummocky' moraine formation: case studies from the northwest Highlands, Scotland. Boreas, 34, 287-307.

Maizels, J. (1995) Sediments and landforms of modern proglacial terrestrial environments. In: Modern Glacial Environments: Processes, Dynamics and Sediments (Ed. J. Menzies), pp. 365-415. Butterworth-Heinmann, Oxford.

Manley, G. (1959) The Late-glacial climate of north-west England. Liverpool Manchester Geol. J., 2, 188-215. 
Matthews, J.A. and Petch, J.R. (1982) Within-valley asymmetry and related problems of Neoglacial lateral moraine development at certain Jotunheim glaciers, southern Norway. Boreas, 11, 225-247.

McDougall, D.A. (2001) The geomorphological impact of Loch Lomond (Younger Dryas) Stadial plateau icefields in the central Lake District, northwest England. $J$. Quatern. Sci., 16, 531-543.

Moncrieff, A.C.M. (1989) Classification of poorly sorted sedimentary rocks. Sed. Geol., 65, 191-194.

Pennington, W. (1978) Quaternary Geology. In: The Geology of the Lake District (Ed. F. Moseley), pp. 207-225. Yorkshire Geological Society, Yorkshire.

Price, R.J. (1970) Moraines at Fjallsjökull, Iceland. Arctic Alpine Res., 2, $27-42$.

Rose, J. (1987) Drumlins as part of a glacier bedform continuum. In: Drumlin Symposium (Eds J. Menzies and J. Rose), pp. 103-116. Balkema, Rotterdam.

Ruszczynska-Szenajch, H. (2001) Glaciodynamically upthrusted bands of englacially transported debris in the Pleistocene of central Poland. Sedimentology, 48, 585-597.

Sissons, J.B. (1979) The Loch Lomond Stadial in the British Isles. Nature, 280, 199203.

Sissons, J.B. (1980) The Loch Lomond Advance in the Lake District, northern England. Trans. Roy. Soc. Edinb. Earth Sci., 71, 12-27. 
Small, R.J. (1983) Lateral moraine of Glacier de Tsidjiore Nouve: form, development, and implications. J. Glaciol., 29, 250-259.

Sneed, E.D. and Folk, R.L. (1958) Pebbles in the lower Colorado River, Texas, a study of particle morphogenesis. J. Geol., 66, 114-150.

Sollid, J.L. and Sørbel, L. (1988) Influence of temperature conditions in formation of end moraines in Fennoscandia and Svalbard. Boreas, 17, 553-558.

Ward, C. (1873) The glaciation of the northern part of the Lake-District. Q. J. Geol. Soc. London, 29, 422-441.

Wilson, S.B. and Evans, D.J.A. (2000) Coire a' Cheund-chnoic, the "hummocky moraine" of Glen Torridon. Scot. Geogr. J., 116, 149-158. 


\section{Figure captions}

Fig. 1. The location of the field site in the English Lake District

Fig. 2. Outline geomorphological map of upper Ennerdale showing the distribution of the key sediment-landform associations and the locations of clast and matrix samples

Fig. 3. (a) Typical clast form and matrix grain-size information for the diamicton (D), gravel (G), and control samples. (b) Co-variant plot of the RA and $\mathrm{C}_{40}$ indices.

Fig. 4. (a) The oblique ridges on the Tongue $\left(A_{1}\right)$ viewed from the southern side of the valley. Mounds of the valley-floor moraine mound complex $\left(\mathrm{A}_{4}\right)$ are visible in the centre-left of the photograph. (b) The valley-side moraine-mound complex $\left(\mathrm{A}_{2}\right)$ viewed from the head of Ennerdale. The structure of the complex becomes increasingly ordered down-valley (further away from the photographer). (c) View from within the valley-side moraine-mound complex $\left(\mathrm{A}_{2}\right)$ looking up-valley along the rectilinear faces of several mounds. The imbricate relationships between individual mounds are clear.

Fig. 5. (a) Digital elevation model of part of the valley-side moraine-mound complex $\left(A_{2}\right)$. Faces to the right are commonly rectilinear, whilst those to the left are less regular. (b) Profiles along and across the ridge crests in the valley-side morainemound complex $\left(\mathrm{A}_{2}\right)$. Heights and distances in metres relative to an arbitrary datum. Dashed lines indicated inferred tectonic contacts.

Fig. 6. (a) Structural map of the valley-side moraine-mound complex $\left(\mathrm{A}_{2}\right)$ and valleyside subdued ridges $\left(\mathrm{A}_{3}\right)$. Ridge-crest orientations and directions of dip of rectilinear 
faces are marked. (b) Schmidt lower-hemisphere equal-area stereographic projection of the dip and direction of dip of rectilinear faces in the valley-side moraine-mound complex $\left(\mathrm{A}_{2}\right)$. (c) Frequency of dips of rectilinear faces in the valley-side morainemound complex $\left(\mathrm{A}_{2}\right)$. (d) Rose diagrams illustrating the direction of dip of rectilinear faces in the valley-side moraine-mound complex $\left(\mathrm{A}_{2}\right)$ at $5^{\circ}$ intervals. The vector mean, its confidence interval and the direction to Kirk Fell are marked. (e) Rose diagrams illustrating the orientations of ridge crests in the valley-side moraine-mound complex $\left(\mathrm{A}_{2}\right)$ and valley-side subdued ridges $\left(\mathrm{A}_{3}\right)$ at $5^{\circ}$ intervals. The vector mean, its confidence interval and the direction to Kirk Fell are marked. The number of mounds in each diagram varies between (d) and (e) because not all mounds have distinct ridge crests or rectilinear faces. 
Table 1: Summary of the physical properties of the facies observed in Ennerdale.

Textural descriptions based on the classification of Moncrieff (1989) for poorly sorted sediments.

\begin{tabular}{|c|c|c|c|c|c|c|}
\hline Facies & $\begin{array}{l}\text { n (clast } \\
\text { samples) }\end{array}$ & $\begin{array}{l}\text { Textural } \\
\text { description }\end{array}$ & $\mathrm{C}_{40}$ index & RA index & $\begin{array}{l}\text { Faceted } \\
\text { clasts }\end{array}$ & $\begin{array}{l}\text { Striated } \\
\text { clasts }\end{array}$ \\
\hline Gravel (G) & 7 & $\begin{array}{l}\text { Muddy sandy- } \\
\text { gravel }\end{array}$ & $\begin{array}{l}\text { 8-21 (mean } \\
=14.5)\end{array}$ & $\begin{array}{l}\text { 4-18 (mean } \\
=10)\end{array}$ & $0-8 \%$ & $4-24 \%$ \\
\hline Diamicton (D) & 10 & $\begin{array}{l}\text { Clast-rich } \\
\text { sandy } \\
\text { diamicton }\end{array}$ & $\begin{array}{l}\text { 8-35 (mean } \\
=19)\end{array}$ & $\begin{array}{l}\text { 0-36 (mean } \\
=9 \text { ) }\end{array}$ & $0-8 \%$ & $0-22 \%$ \\
\hline $\begin{array}{l}\text { River channel } \\
\text { (CS1) }\end{array}$ & 2 & - & 35,40 & 0 & 0 & 0 \\
\hline $\begin{array}{l}\text { Scree slope } \\
\text { (CS2) }\end{array}$ & 2 & - & 80,86 & 66,70 & 0 & 0 \\
\hline
\end{tabular}


Table 2: Summary of the probable origin of each of the sediment-landform associations. Indication of probability ranges from no ticks (very unlikely) to three ticks (most likely).

Possible origin

\begin{tabular}{|c|c|c|c|c|}
\hline \multirow{2}{*}{ Sediment-landform } & & \multirow[b]{2}{*}{$\begin{array}{l}\text { Active ice- } \\
\text { margin } \\
\text { recession }\end{array}$} & & \\
\hline & $\begin{array}{l}\text { Subglacial } \\
\text { deformation }\end{array}$ & & Ice stagnation & $\begin{array}{l}\text { Englacial } \\
\text { thrusting }\end{array}$ \\
\hline Oblique ridges $\left(A_{1}\right)$ & & $\sqrt{ } \sqrt{ } \sqrt{2}$ & & \\
\hline $\begin{array}{l}\text { Valley-side moraine- } \\
\text { mound complex }\left(A_{2}\right)\end{array}$ & $\sqrt{ }$ & $\sqrt{ } \sqrt{ }$ & $\sqrt{ }$ & $\sqrt{ } \sqrt{ } \sqrt{ }$ \\
\hline $\begin{array}{l}\text { Valley-side subdued } \\
\text { ridges }\left(A_{3}\right)\end{array}$ & $\sqrt{ }$ & $\sqrt{ } \sqrt{ } \sqrt{2}$ & & \\
\hline $\begin{array}{l}\text { Valley-floor moraine- } \\
\text { mound complex }\left(A_{4}\right)\end{array}$ & $\sqrt{ }$ & & $\sqrt{ } \sqrt{ }$ & $\sqrt{ } \sqrt{ }$ \\
\hline
\end{tabular}




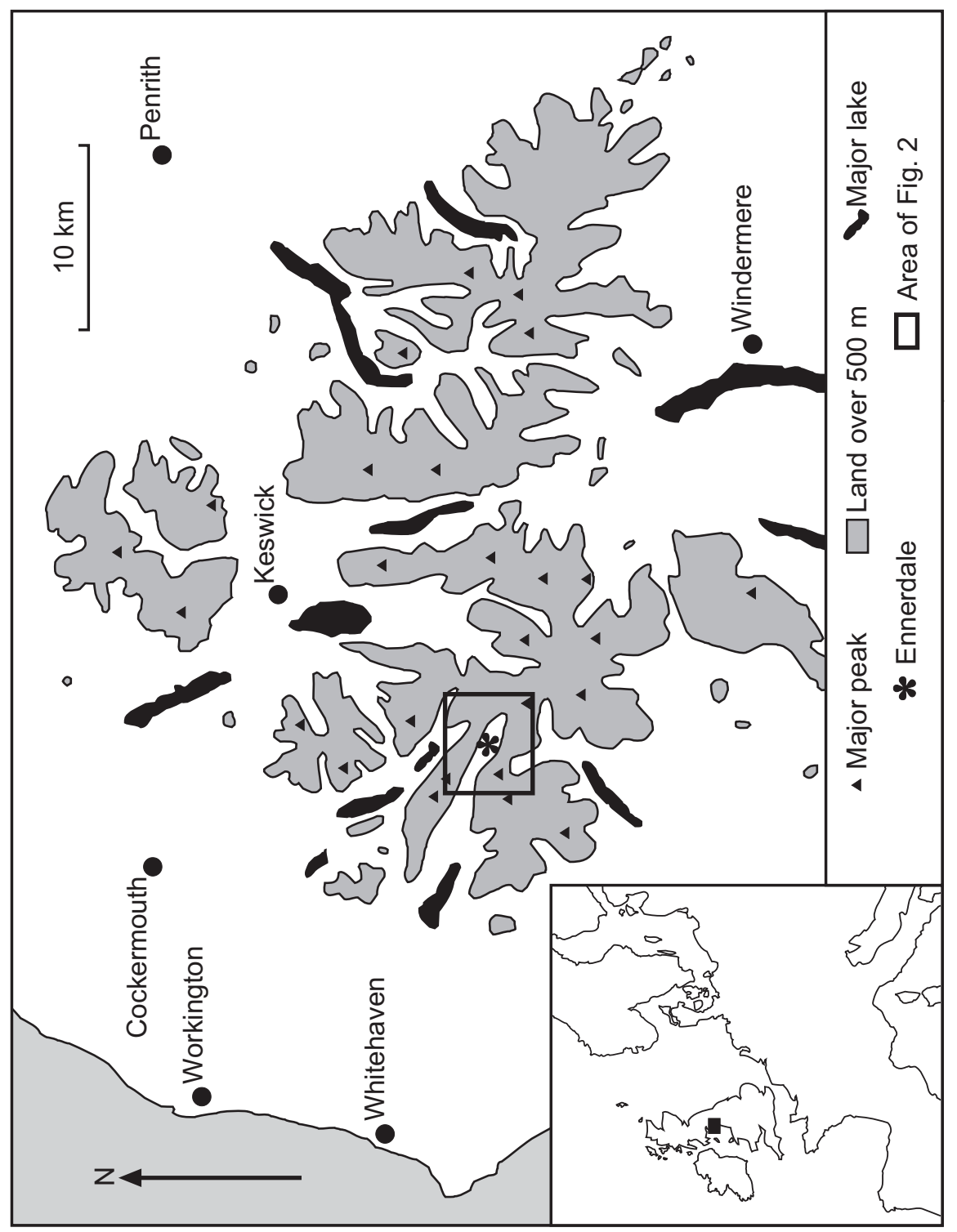




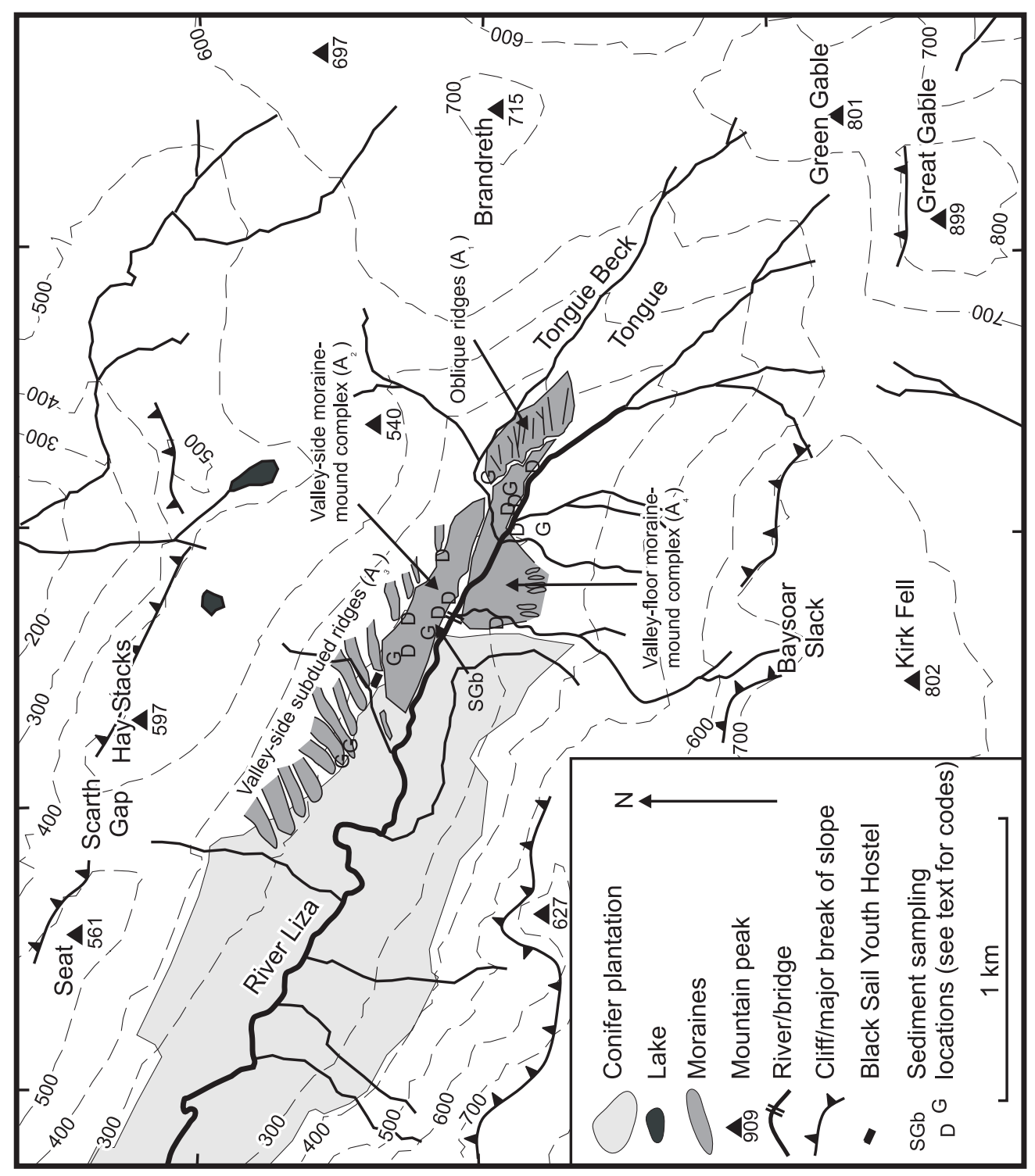


(a)

Gravel (G)
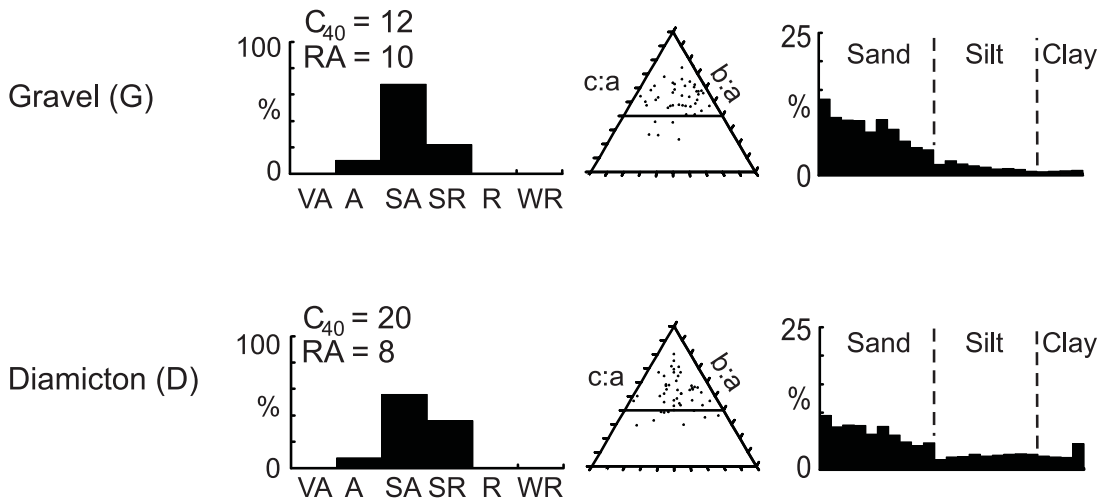

Control:

fluvial (CS1)
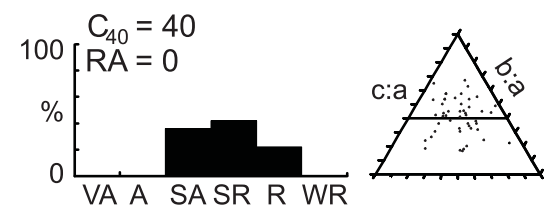

scree (CS2)
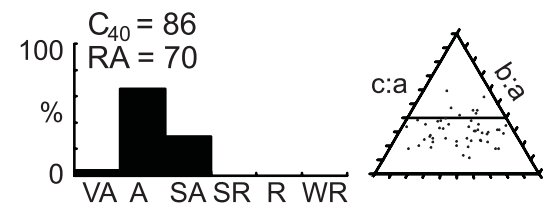

(b)

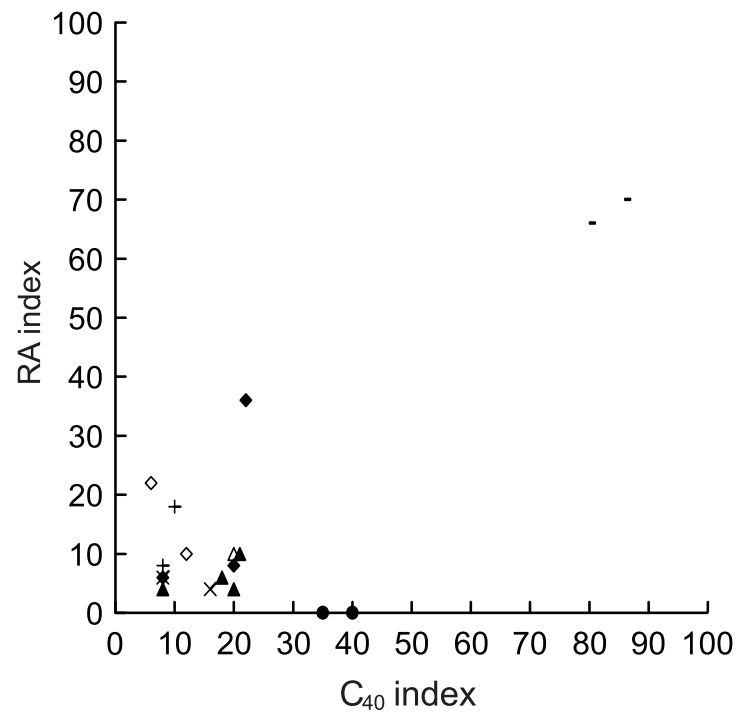

- Fluvial

- Scree

Valley-side moraine-mound complex:

$\diamond$ Gravel

- Diamicton

Valley-floor moraine-mound complex:

$\triangle$ Gravel

^ Diamicton

Southern valley side:

$\times$ Gravel

Valley-side subdued ridges:

+ Gravel

$\mathrm{C}_{40}$ index 
(a)

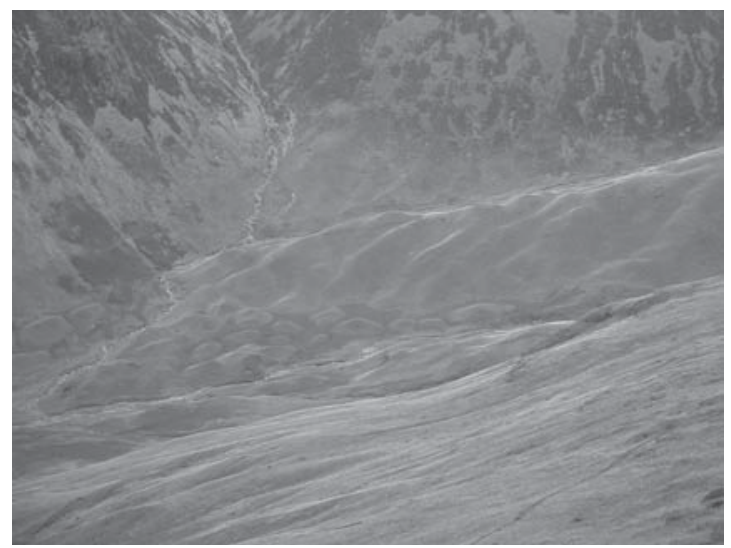

(b)

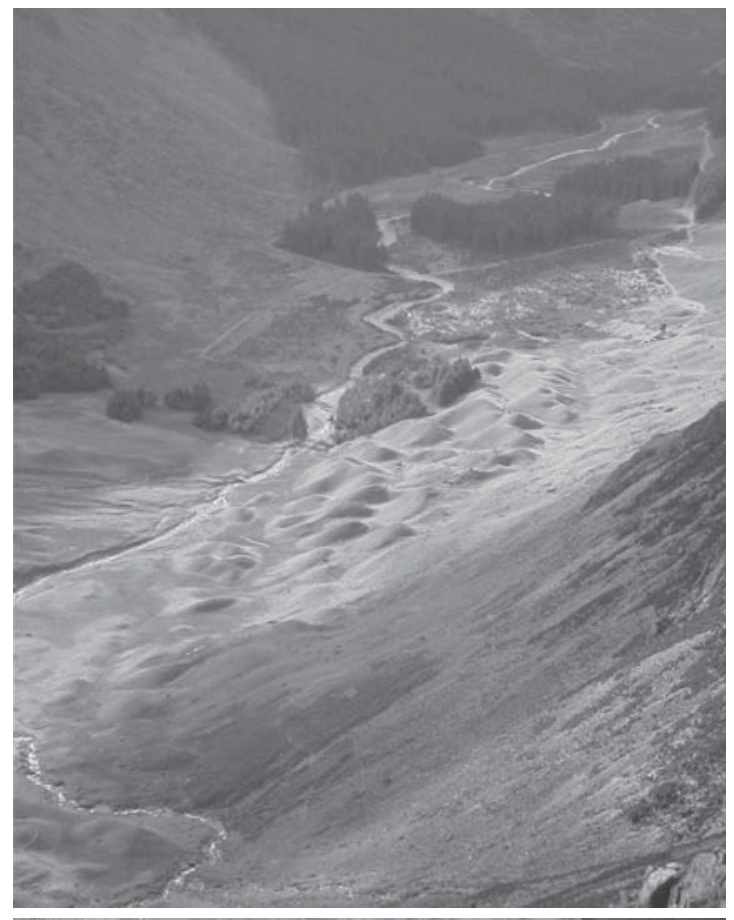

(c)

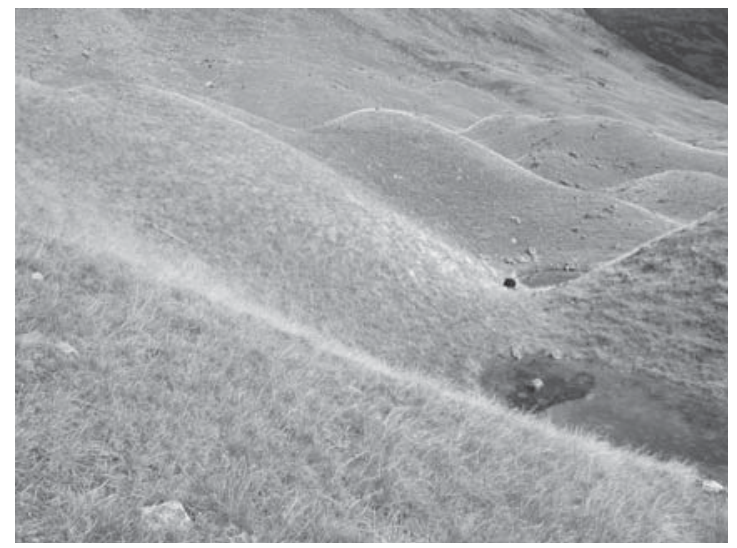




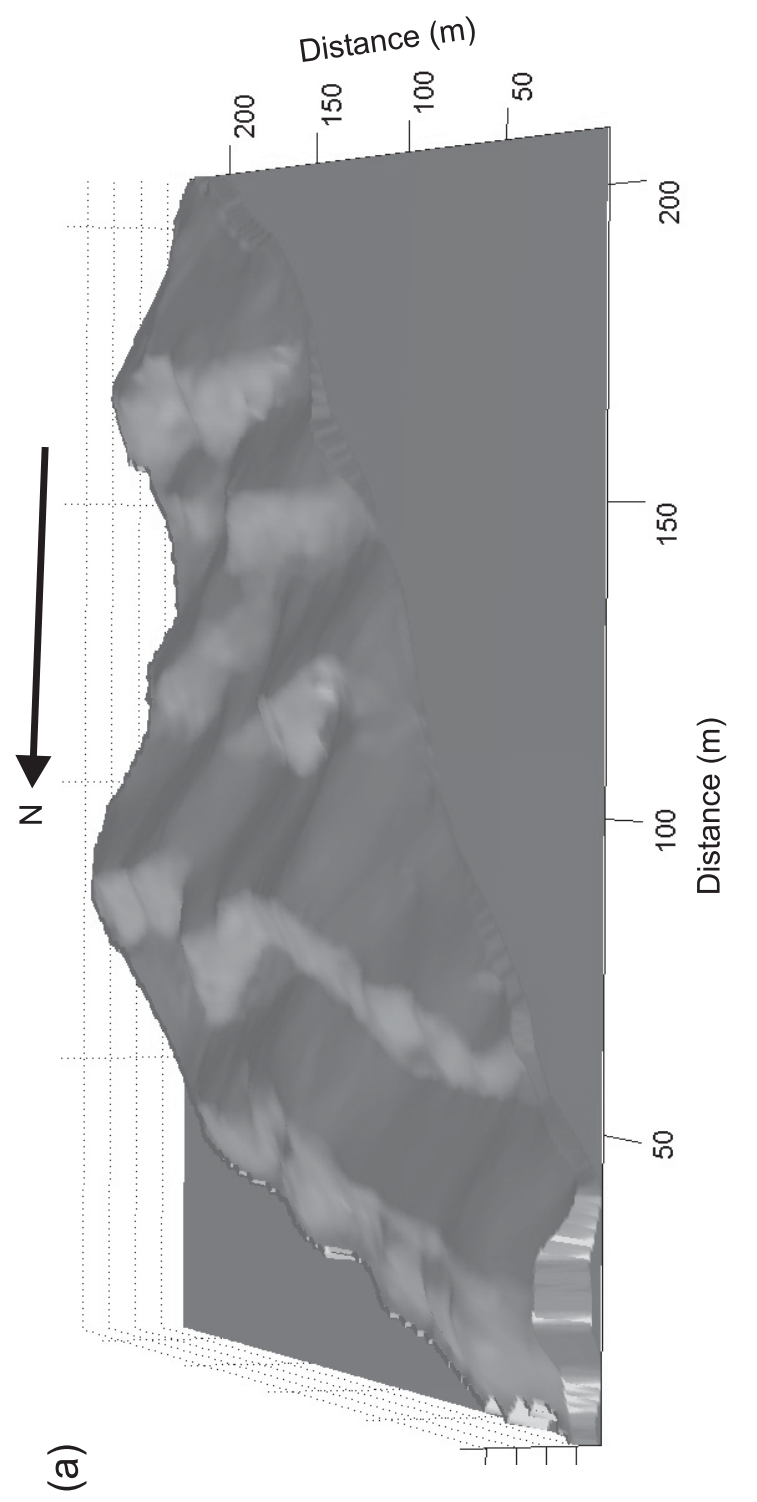


(b)
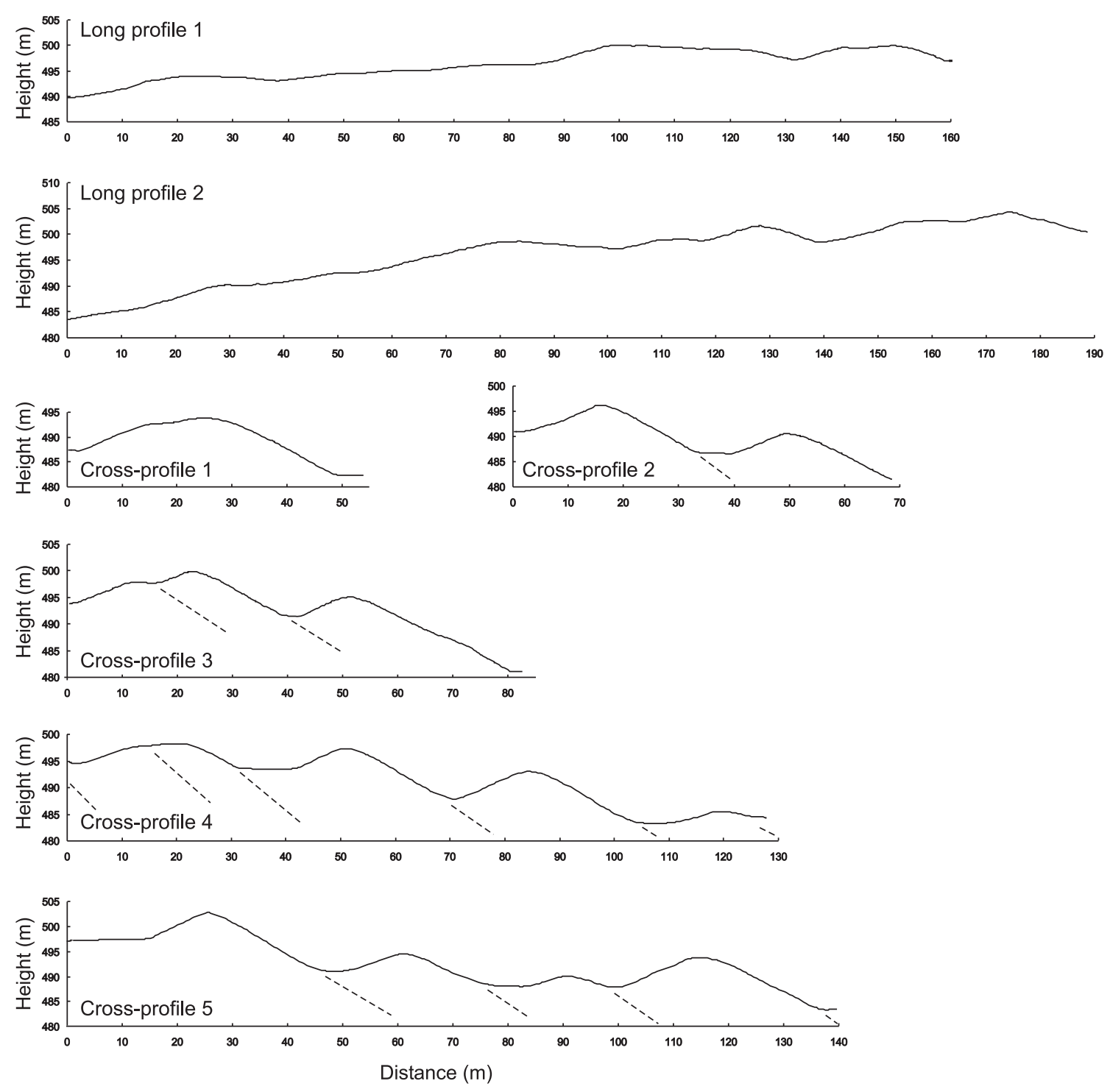


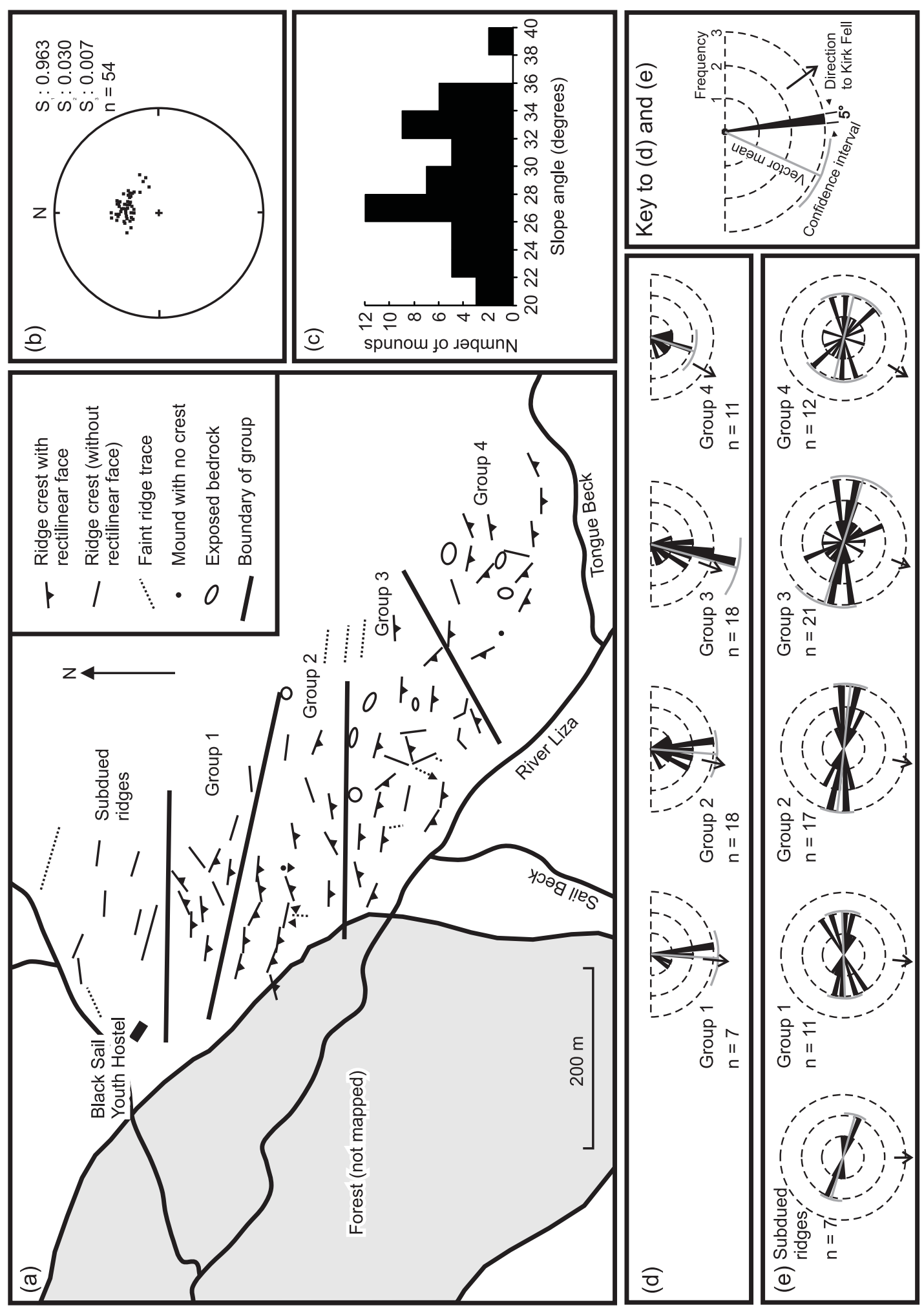

